\title{
Prinsip kehadiran dalam novel-novel Jong Chian Lai: Analisis teksdealisme
}

\author{
Textsdealisme analysis: Principles of presence in Jong Chian Lai novels
}

\author{
Sara Beden \\ sara.beden@ipgmktar.edu.my
}

Institut Pendidikan Guru Kampus Tun Abdul Razak, Kuala Lumpur, Malaysia

DOI: https://doi.org/10.37134/pendeta.vol10.4.2019

\begin{abstract}
ABSTRAK
Pembaharuan atau inovasi sentiasa dilakukan oleh pengarang yang prolifik dalam berkarya dengan menghadirkan pelbagai sumber dan idea untuk meletakkan teks ciptaannya mencapai tahap keunggulan. Justeru, kepelbagaian dan kesegaran sumber menjadi keutamaan seseorang pengarang dalam berkarya. Jong Chian Lai sebagai penulis yang prolifik di Sarawak sedar akan kepentingan melakukan pembaharuan dalam menghadirkan sumber dan idea yang baharu dalam teks-teks ciptaannya. Sehubungan itu, makalah ini bertujuan untuk menganalisis prinsip kehadiran dalam tiga buah novel karya Jong Chian Lai berdasarkan teori Teksdealisme. Teori Teksdealisme mengandungi empat prinsip yang dapat digunakan untuk mengukur tahap kualiti kepengarangan seseorang pengarang. Kajian ini hanya mengaplikasikan prinsip kehadiran untuk menganalisis novel Gugurnya Langit Hijau Nanga Tiga (1986), Pemberontakan (1994) dan Ensera Marga Timur dari St Anthony (2009). Kajian ini menggunakan kaedah analisis teks dan kaedah kepustakaan. Hasil dapatan analisis memperlihatkan bahawa Jong Chian Lai sentiasa membuat inovasi atau pembaharuan dalam ketiga-tiga novel dalam usaha menghadirkan kepelbagaian sumber dan idea yang baharu menerusi pengalaman peribadi dan penyelidikan. Pembaharuan ini diteliti menerusi sumber idea, struktur dan aliran dalam ketiga-tiga teks. Struktur penciptaannya mengalami perubahan selain memperlihatkan pengekalan terhadap struktur tertentu. Aliran turut menunjukkan pembaharuan dari realisme kepada aliran realisme magis. Impaknya, setiap teks ciptaannya menunjukkan pembaharuan dan pemantapan yang dilakukan dari semasa ke semasa bagi mencapai tahap unggul sekali gus memberikan perangsang kepada penulis-penulis lain agar sentiasa membuat pembaharuan dalam penciptaan.
\end{abstract}

Kata kunci: teksdealisme, pembaharuan, aliran, struktur, idea

\begin{abstract}
Innovations and improvments have always been the focus of prolific authors by presenting various resources and ideas in order to uplift their creative texts to the level of excellence. Therefore, the diversity and freshness of the source have been put as the priority in their work. Jong Chian Lai, as a prolific writer in Sarawak, is aware of the importance of bringing new resources and ideas into his texts. Thus, the paper aims to analyze Jong Chian Lai's novels based on the principle of presence in textdealism. The textdealism theory consists of four principles used to measure the quality of an author's authorship. This study only applies the principle of presence in analysing the novels of Gugurnya Langit Hijau Nanga Tiga (1986), Pemberontakan (1994) dan Ensera Marga Timur dari St Anthony (2009). This study uses text and literature analysis methods. The findings indicate that Jong Chian Lai always innovates or improves all the three novels in order to insert new sources and ideas through personal experiences and research. This reform is examined through the source of ideas, structure and flow in all three texts. His structure creation goes through changes besides displaying the retention of certain structures. The flow also shows the renewal of realism to the magical realism flow. As a result, each text reflects the improvements and enhancement which are conducted from time to time, thus, this has encouraged other authors to always improve their works.
\end{abstract}

Keywords: textdealism, renewal, flow, structure, idea 


\section{PENGENALAN}

Pengarang mempunyai kedudukan yang istimewa sejak zaman berzaman. Kepekaan atau sensitiviti dan keprihatinan pengarang ialah sifat yang membezakan pengarang daripada masyarakat umum. Seseorang yang bergelar pengarang atau sasterawan memiliki sifat filosuf atau sekurang-kurangnya sebagai pemikir. Ramai pengarang muncul dan memberikan sumbangan dalam dunia sastera tanah air. Penulis dan pengarang dari Bumi Kenyalang turut mewarnai dan memeriahkan persada sastera tanah air dalam usaha memberikan sumbangan untuk mengangkat martabat sastera tanah air. Seorang novelis berbangsa Cina yang menjadi kebanggaan negara khususnya negeri Sarawak sehingga kini ialah Jong Chian Lai. Beliau merupakan pengarang yang prolifik dalam penulisan cerpen dan novel sehingga sering memenangi sayembara penulisan pada peringkat nasional dan negeri. Penglibatan beliau sungguh bermakna dalam perkembangan sastera tanah air sehingga mendapat pelbagai anugerah dan hadiah. Anugerah tertinggi yang diraih beliau setakat ini ialah S.E.A Write Award 2006 dalam genre novel dari Kerajaan Thailand. Kemenangan yang diperolehi beliau khasnya dalam genre cerpen dan novel memperkukuh ketokohan dan memantapkan gaya penulisan beliau dari segi persoalan, pemikiran, teknik dan gaya bahasa.

Jong Chian Lai turut dikenali sebagai perakam dan pengkritik sosial yang tekun, prihatin dan kritis seperti yang terpapar dalam teks-teks ciptaannya. Dalam berkarya, beliau ingin mencetuskan kesedaran kepada khalayak agar mengamalkan nilai hidup yang murni dan mengetepikan nilai yang negatif. Oleh itu, tidak hairanlah karya-karya beliau amat sarat dengan kritikan sosial, nilai moral dan kemanusiaan serta unsur pemikiran yang menyarankan pembaharuan dan kemajuan. Kesedaran yang ketara di pihak Jong adalah untuk membawa suara pinggiran masyarakat subaltern, terutama di Sarawak. Jeniri Amir (2007) menjelaskan bahawa hal ini dilakukannya untuk menjadi metanaratif di arus perdana sastera kebangsaan kerana yakin bahawa sastera dapat dijadikan sebagai jambatan untuk meruntuhkan tembok pemisahan antara kaum di Malaysia. Sementara Jais Sahok (2000) pula menegaskan bahawa kejayaan Jong amat besar dalam persada kesusasteraan Melayu nasional. Keunikannya bertitik tolak atas faktor kejayaannya mengetengahkan karya-karya yang berlatarbelakangkan masyarakat Iban sedangkan beliau berketurunan Tionghua. Pernyataan dan pandangan daripada tokoh-tokoh tersebut membuktikan ketokohan Jong sebagai penulis yang prolifik dan pemikir yang intelek kerana sedar akan tanggungjawabnya sebagai seorang penulis. Tugas seorang penulis sangat berat dan memerlukan mereka membuat penaakulan tentang dasar dan arah tuju penciptaan mereka agar meninggalkan impak yang bermanfaat kepada masyarakat dan bangsanya.

Sastera tidak terhasil dengan kekosongan dan kejahilan. Oleh itu, sumber-sumber yang berlegar di persekitaran, pengalaman, pemerhatian, pembacaan, perenungan dan penyelidikan dikongsi dan ditukangi sehingga menjadi kesatuan pemikiran. Mana Sikana (1996), menyatakan bahawa "Idea dan pengalaman mempunyai hubungan rapat dengan sifat jati diri. Idea dan pengalaman akan mencorak dan membentuk subjek karya" (hlm.60). Selaras dengan pernyataan tersebut, kehadiran atau asal usul sumber idea pengarang dalam penciptaannya menjadi titik tolak permasalahan kajian ini. Apa-apa sahaja genre memerlukan idea yang dapat dianalogikan sebagai "jiwa" dan "jantung" dalam sesebuah karya. Idea harus matang, unik, segar dan komprehensif agar proses penciptaan berjalan lancar. Oleh itu, sudah tentu pelbagai tindakan dan strategi yang dilakukan pengarang agar sumber idea teks-teks ciptaan memperlihatkan kesegaran, pembaharuan dan keberanian bagi membentuk subjek karya yang mempunyai pertalian dengan jati diri penulis. Perkara ini juga bertaut erat dengan cita-cita penulis. Jong Chian Lai (2000) menjelaskan bahawa cita-citanya untuk mencetuskan kesedaran kepada individu atau masyarakat tentang kehidupan berkualiti. Berdasarkan pendapat tersebut, dapat diperjelas bahawa pengarang memiliki misi dan visi nasional dalam pengkaryaannya untuk memugar transformasi minda dalam kalangan khalayak agar tidak dibelenggu kepercayaan dan prinsip yang boleh memundurkan kualiti kehidupan. Dalam konteks ini, pandangan Mana Sikana (1996) bahawa idea dan pengalaman akan mencorak dan membentuk subjek karya pengarang adalah sangat signifikan dan berasas. Pengarang akan menggunakan pelbagai strategi agar sumber idea dalam teks-teks ciptaannya memperlihatkan pembaharuan dan tidak berada di takuk lama selain memperlihatkan sifat jati diri sekali gus berkeupayaan dan berfungsi memberikan kesedaran dan motivasi kepada masyarakat. Perkara ini bertepatan dengan penegasan Ariff Mohamad (2015, hal. 231) yang menyifatkan bahawa sesebuah karya kreatif antara lain bertujuan untuk menyampaikan pengajaran, dakwah dan pesan kepada 
pembaca. Sesebuah karya sastera yang berupaya mendidik dan memotivasikan masyarakat sewajarnya menghadirkan sumber idea yang berkualiti dan memperlihatkan pembaharuan. Justeru, kajian ini memberikan fokus terhadap proses merungkai kehadiran sumber idea Jong Chian Lai dalam berkarya sehingga membentuk tekstual teks sekali gus mencapai tahap kepengarangannya.

Sehubungan itu, setiap pengarang secara umumnya sentiasa berhasrat untuk mencapai tahap kepengarangan dalam berkarya dengan menggunakan pelbagai sumber. Dalam hal ini tidak semua pengarang akan berjaya membentuk dan mencapai tahap kepengarangannya malah ada yang tidak dapat menghasilkan karya yang bermutu. Keadaan ini berlaku disebabkan usaha membentuk kepengarangan bukanlah mudah dan menuntut ketekunan, kesungguhan dan jangka masa yang lama. Tengku Intan Marlina Tengku Mohd. Ali, Madiawati Mamat@Mustaffa dan Fauzi Hasan (2017), dalam penelitiannya terhadap karya-karya Faisal Tehrani berdasarkan teori Tekdealisme mendapati bahawa novel-novel Faisal Tehrani berbeza dengan karya-karya pengarang-pengarang seangkatan disebabkan oleh keupayaan dan kemampuannya mengolah pemikiran, mesej, teknik dan seumpamanya setelah melalui suatu tempoh berkarya. Ringkasnya, kajian ini diharap dapat memperlihatkan kepengarangan Jong Chian Lai dalam usaha menghadirkan sumber idea dalam berkarya berdasarkan prinsip kehadiran dalam teori Teksdealisme menerusi tiga buah novel pilihan, iaitu Gugurnya Langit Hijau Nanga Tiga (GLHNT) 1986, Pemberontakan (1994) dan Ensera Marga Timur dari St Anthony (EMTSA) 2009.

\section{OBJEKTIF KAJIAN}

Makalah ini bertujuan untuk menganalisis prinsip kehadiran dalam tiga buah Jong Chian Lai berdasarkan teori Teksdealisme. Prinsip kehadiran merupakan prinsip pertama dalam teori Teksdealisme yang menuntut seseorang pengarang untuk menghadirkan sumber dan idea yang baharu daripada pelbagai sumber agar teks mencapai tahap unggul.

\section{BAHAN KAJIAN}

Sebanyak tiga buah novel telah dipilih untuk dikaji, iaitu novel GLHNT (1986), Pemberontakan (1994) dan EMTSA (2009). Novel-novel yang dipilih mempunyai kekuatan dan keistimewaan yang tersendiri serta menggambarkan perubahan dan pembaharuan pengarang dalam berkarya. Tambahan pula ketigatiga novel tersebut telah memenangi peraduan dan sayembara penulisan novel yang sudah pasti memiliki kekuatan dan keistimewaannya. GLHNT merupakan novel yang telah memenangi Hadiah Pertama bahagian novel dalam Peraduan Menulis Sastera Kreatif V (1982/1983) anjuran Dewan Bahasa dan Pustaka Cawangan Sarawak (DBPCS). Pemberontakan pula merupakan novel yang memenangi tempat kedua dalam Sayembara Menulis Novel ESSO-GAPENA 1993 dan novel ini terpilih sebagai siri Penerbitan Abad ke-20 oleh Dewan Bahasa dan Pustaka. Novel Pemberontakan juga merupakan novel sejarah pertama berbentuk kreatif di peringkat negeri Sarawak seperti yang dihasrat pengarangnya. Ensera Marga Timur dari St. Anthony pula merupakan novel yang memenangi Hadiah Ke-3 sempena Peraduan Menulis Sastera Kreatif Budaya Sarawak 2003/2005. Kriteria yang mewajarkan pemilihan karya-karya ini adalah berasaskan tiga pertimbangan. Pertama, novel-novel yang dipilih mempunyai kekuatan dan keistimewaan yang tersendiri khasnya dari sudut sumber pengarang menghadirkan pengalaman yang sentiasa segar dan mempunyai unsur pembaharuan. Kedua, novel-novel tersebut juga memaparkan idea dan pemikiran pengarang yang mantap dan berani serta besar dalam membawa pembaharuan dan merungkai permasalahan sosial masyarakat atau etnik terpinggir yang menjadi subjek pengkaryaannya. Ketiga, ketiga-tiga novel mewakili jarak masa yang berbeza sepanjang pengarang berkarya. GLHNT merupakan novel beliau yang pertama, Pemberontakan pula dicipta di tengah-tengah perjuangan dan nama beliau melonjak naik dalam bidang kesusasteraan dan EMTSA merupakan novel yang diterbitkan pada tahun 2009 dalam kategori novel umum. Keadaan ini membolehkan pengkaji meneliti apakah pengekalan, perubahan, pembaharuan dan kemantapan pengarang berkarya khususnya dalam menghadirkan sumber idea dalam tempoh masa berkenaan. 


\section{KERANGKA TEORITIS}

Kajian ini adalah berasaskan teori teksdealisme yang diasaskan oleh Mana Sikana. Teksdealisme ialah rangkuman daripada dua kosa kata iaitu 'teks' dan 'idealisme' yang membawa maksud teks atau karya yang ideal atau unggul. Teori teksdealisme bertitik tolak daripada premis bahawa setiap pengarang mempunyai hasrat untuk mencapai suatu tahap keunggulan dalam penciptaan karya-karyanya. Oleh itu, seseorang pengarang akan berusaha dengan bakat, kebolehan, daya intelektual dan ketrampilannya bagi menghasilkan karya yang bermutu dan lebih baik daripada yang pernah dihasilkan sebelumnya. Mana Sikana (2006) menegaskan bahawa "pengarang juga dituntut mencapai keunggulan yang bermakna mempunyai nilai yang tinggi, luar biasa, cemerlang dan memiliki kekuatan untuk bertahan dalam ujian masa dan zaman. Keunggulan juga bererti membawa budaya sastera ke suatu tahap yang tinggi baik di peringkat kebangsaan juga antarabangsa" (hlm. 73). Berdasarkan teori Teksdealisme, sesuatu karya dianggap unggul apabila wujud kehadiran, berlakunya perlanggaran, mantapnya pengukuhan dan terciptanya individualisme seseorang pengarang sepanjang mengabdikan dirinya dalam penciptaan.

Menurut Mana Sikana (2007) “... teori teksdealisme atau teori keunggulan mendefinisikan teks sebagai susunan idea dan pengalaman yang mengandungi makna yang berlapis-lapis dengan mempunyai sifat-sifat keunggulannya" (hlm. 495). Sifat-sifat keunggulan ini merujuk kepada sifat berani dan bijaksana seseroang pengarang dalam mengemukakan idea dan pengalaman yang telah diperolehinya. Idea dan pengalaman tersebut juga hendaklah sentiasa menggambarkan pembaharuan agar dapat memberikan makna yang baharu dan seterusnya menghasilkan karya yang memperlihatkan mutu dan keunggulan. Pengarang harus berani melahirkan teks sebagai demonstrasi intelektualisme dan mengaplikasikan konstruktif epistemologisme yang berhubung dengan metafizika dan falsafah. Kerja mengarang bukan sahaja memaparkan kisah manusia tetapi turut merangkumi jiwa, roh dan batin yang menyangkut pada akliah logik seninya yang membawa pemikiran khalayak mendasari ke dasar masalah. Usaha-usaha pengarang mencernakan teks akhirnya membawa pada keunggulan (Mana Sikana, 2006). Empat prinsip teori teksdealisme ialah kehadiran, perlanggaran, pengukuhan dan individualisme. Keempat-empat prinsip ini akan dapat meggambarkan keunggulan pengarang sepanjang terlibat dalam dunia penulisan.

Prinsip kehadiran berdasarkan teori Teksdealisme merujuk kepada kehadiran pengalaman dan teks ialah hasil kehadiran idea daripada pengalaman pengarang yang mempengaruhi daya kreativitinya. Menurut Mana Sikana (2006) "Pengalaman tersebut akan membentuk suatu idea yang unggul dan dikemukakan dalam penciptaan teks. Dalam proses penciptaan atau penulisan, kehadiran akan terus berlaku dalam pemikiran pengarang sehinggalah teks tersebut disiapkan" (hlm.105). Teks yang ideal atau unggul bermula daripada idea dan pengalaman. Idea merujuk kepada lintasan-lintasan pemikiran yang terkandung dalam kesedaran pengarang yang mengembang dan mendewasakan, kemudian dijalinkan dalam bentuk teks kreatif. Pengalaman pula ialah sumber yang mencetuskan idea itu dan pengalaman bergerak dalam sublimasi secara tidak sengaja bagi membentuk subjek. Subjek yang dibincangkan dalam karya akan memudahkan pengarang tersebut dikenali.

Kehadiran memperlihatkan bagaimana pengarang memilih, menyaring dan menyempurnakan maklumat-maklumat yang datang daripada idea dan pengalaman. Seseorang pengarang akan memilih unsur-unsur atau bentuk-bentuk pengalaman yang benar-benar sesuai, mantap, bermakna dan bernilai sebelum menghadirkan pengalaman-pengalaman tersebut. Pengalaman seseorang pengarang itu termasuklah antaranya isu atau peristiwa, jalinan, teknik, wawasan, pemikiran, tokoh, gaya bahasa dan latar. Idea dari pengalaman yang hadir dalam pemikiran pengarang tidak terbatas sumber dan rujukannya. Situasi ini bermakna sumber idea tidak mempunyai sekatan dan syarat-syaratnya. Pelbagai sumber boleh dirujuk sama ada melalui pengalaman, bacaan dan pemerhatian pengarang. Jika seseorang pengarang hendak menulis tentang nasionalisme, pengarang perlu meninjau pengalaman sejarah dan membaca buku-buku sejarah atau mengungkapkan pengalaman yang dialaminya sendiri semasa zaman penjajahan. Unsur-unsur kehadiran termasuklah apa-apa sahaja yang terlintas dan mengunjungi serta bertandang dalam pemikiran pengarang. Antaranya adalah seperti bayangan, kemasukan, ingatan, kenangan, penghijrahan, kutipan dan pengaruh. Mana Sikana (2006) menyifatkan bahawa "selagi unsur-unsur itu dapat menghadirkan pengalaman, selagi itulah unsur-unsur itu dikategorikan sebagai kehadiran" (hlm.107). Pengalaman-pengalaman pengaranglah yang membentuk teks. Dalam Teksdealisme, pengarang dituntut mengumpul pengalaman sebanyak mungkin daripada pelbagai 
sumber dan rujukan. Hal ini demikian kerana teks terbentuk daripada pengalaman pengarang yang diproses, dianyam dan ditenun menjadi sebuah teks daripada pelbagai sumber. Pernyataan tentang sumber yang tidak ada batasannya dapat dbuktikan melalui pendapat Shahnon Ahmad (1979) yang menyatakan bahawa "Sumber idea tidak mempunyai batasannya; sama seperti aspek kehidupan yang tidak juga ada batasannya. Idea itu biasanya bermula dari pengalaman sendiri" (hlm. 28). Sumber idea meliputi kejiwaan manusia, sosial, keluarga, pertentangan nilai dalam masyarakat, politik dan falsafah. Dengan kata lain, sumber meliputi setiap disiplin ilmu dan hidup manusia. Dalam teori Teksdealisme, teks yang dianalisis melalui prinsip kehadiran ini diteliti berdasarkan, iaitu pertama apakah fakta yang hadir dan daripada mana sumber kehadirannya? Kedua, bagaimana fakta itu hadir dalam teks tersebut? Ketiga, apakah fungsi kehadirannya. Perkara-perkara ini dipaparkan menerusi kehadiran subjek dan watak yang ditonjolkan oleh pengarang.

\section{METODOLOGI}

Penelitian ini menggunakan dua kaedah kajian iaitu kaedah kepustakaan dan kaedah analisis teks. Kajian kepustakaan melibatkan pembacaan dan pengumpulan bahan-bahan yang berkaitan dengan tajuk kajian. Sumber utama yang bakal digunakan banyak terdapat dalam bentuk bertulis seperti buku, majalah, jurnal, akhbar, kertas-kertas kerja seminar dan latihan ilmiah. Ketiga-tiga novel tersebut akan dibaca secara terperinci dan menggunakan teknik bacaan secara rapi. Kemudian data-data daripada novel-novel ini dianalisis melalui kaedah analisis teks dengan menggunakan teori Teksdealisme sebagai landasan pengkajian. Kajian ini dibataskan dengan menggunakan prinsip kehadiran dalam teori Teksdealisme. Perungkaian bentuk-bentuk kehadiran dalam analisis berdasarkan teori Teksdealisme adalah berdasarkan kehadiran sumber idea dan aspek struktur (pemikiran, subjek, latar dan watak) dan aliran (sama ada realisme, realisme magis, surealisme). Prinsip kehadiran akan dipertalikan dengan sumber-sumber pengalaman pengarang dalam menghasilkan karya tersebut. Pengalaman yang diperolehi pengarang akan menentukan bentuk-bentuk kehadiran sama ada struktur, unsur, aliran atau ideologi. Kajian ini berlandaskan prinsip kehadiran yang akan dianalisis merangkumi tiga bahagian iaitu: Pertama, apakah fakta-fakta yang dihadirkan? Kedua, bagaimanakah kehadiran itu dilakukan? Ketiga, apakah kesan dan fungsinya kepada teks? Gabungan ketiga-tiga landasan ini akan memperlihatkan kesatuan idea seseorang pengarang dalam membentuk teks ciptaannya.

\section{DAPATAN \& PERBINCANGAN ANALISIS}

Dapatan analisis dalam makalah ini memperlihatkan bahawa aspek kehadiran dalam ketiga-tiga novel diperincikan segi kehadiran sumber idea, struktur dan aliran yang dihadirkan oleh pengarang sebagaimana paparannya dalam jadual 1 berikut:

Jadual 1. Dapatan Analisis

\begin{tabular}{llll}
\hline Novel & Kehadiran Sumber Idea & Kehadiran Struktur & $\begin{array}{l}\text { Kehadiran } \\
\text { Aliran }\end{array}$ \\
\hline GLHNT & Pengalaman Peribadi & Subjek/Watak/Latar & Realisme \\
\hline Pemberontakan & Penyelidikan/Pembacaan/Rujukan & Subjek/Watak/Latar & Realisme \\
\hline EMTSA & Penyelidikan/Pembacaan/Rujukan & $\begin{array}{l}\text { Subjek/Watak/Teknik/Unsur- } \\
\text { Unsur }\end{array}$ & Realisme Magis \\
\hline
\end{tabular}

Berdasarkan dapatan analisis dalam jadual, didapati prinsip kehadiran dalam ketiga-tiga novel diperlihatkan menerusi idea atau sumber pengalaman pengarang yang menunjukkan kepelbagaian sumber, iaitu pengalaman peribadi, penyelidikan, pembacaan dan rujukan sehingga pengarang menghadirkan subjek, latar, watak, teknik, dan unsur yang mengukuhkan teks-teks ciptaannya. Sementara aliran yang dianutinya pula diperlihatkan menerusi aliran realisme dalam novel novel GLHNT (1986) dan Pemberontakan (1994) manakala aliran realisme magis dalam Ensera Marga Timur dari St Anthony (2009). Perbincangan analisis berdasarkan prinsip kehadiran diperlihatkan secara 
turutan, iaitu kehadiran dalam novel GLHNT (1986), Pemberontakan (1994) dan Ensera Marga Timur dari St Anthony (2009).

\title{
KEHADIRAN DALAM GLHNT
}

Dalam konteks proses penciptaan, perkara yang paling signifikan ialah kehadiran sumber idea. Dari manakah sumber idea itu dihadirkan? Berdasarkan sumber idea yang sudah bergumul dan berselirat dalam minda, barulah pengarang menukangi dan mengembangkannya. Prinsip kehadiran dalam GLHNT diperlihatkan menerusi sumber idea, struktur sesebuah karya dan aliran yang dianuti seseorang pengarang. GLHNT ialah novel sulung pengarang yang terhasil semasa beliau bertugas di Bandar Sri Aman pada tahun 1981 dan terhasil daripada sumber pengalaman peribadi beliau. Beliau membuat pemerhatian, penelitian dan catatan daripada peristiwa, fakta, situasi masyarakat dan menggunakan teknik penyoalan dalam usaha mendapatkan sumber idea yang autentik.

\section{Kehadiran Sumber Idea}

GLHNT merupakan rekonstruksi pengalaman peribadi Jong Chian Lai semasa bertugas di Sri Aman. Bandar Sri Aman pada ketika itu sangat aman, sunyi, tenang dan sangat sesuai untuk menulis. Sepanjang menjalankan tugas di Betong, beliau telah meraih banyak pengalaman peribadi dan mengumpulnya sebagai bahan. Seorang penulis wajar mengayakan dirinya dengan pengalaman sebagaimana penegasan Siti Khariah Mohd Zubir \& Nur Aisyah Abdullah (2015) bahawa seorang penulis kreatif perlu mempunyai bakat, perlu mengalami banyak pengalaman, perlu menimba ilmu terutamanya daripada bahan-bahan dan perlu kepada disiplin diri yang baik. Jong Chian Lai menggunakan peluang bertugas di daerah Betong sebagai platform untuk menggali dan mencungkil seberapa banyak idea bagi memudahkan penghasilan teksnya. Jong Chian Lai (2007) menjelaskan bahawa bandar itu terkenal sebagai tempat yang dikepung suara-suara 'benak' yang mengganas di Sungai Batang Lupar, kaum Iban, rumah panjang, hutan hijau, sungai jernih, perahu panjang, cerita dongeng dan adat resam. Tambahan pula, pada waktu itu bandar ini belum lagi diasak pembangunan yang pesat dan kebanyakan kawasan pedalaman masih diselimuti hutan yang menghijau. GLHNT bersumberkan pengalaman peribadi beliau ketika bertugas di Betong, Sri Aman yang suasananya amat merangsang ilham dan pengalaman inilah yang dihadirkan oleh beliau dalam GLHNT. Menurut Jong Chian Lai (2000):

\begin{abstract}
"Saya seorang pencinta alam semulajadi. Sewaktu itu, saya bertugas di Bandar Sri Aman dengan suasana yang damai, sepi, kaku seperti memenjarakan diri ini untuk menghasilkan novel tersebut. Saya belajar bercakap Iban dan fasih begitu cepat kerana saya sudah fasih dalam bahasa Melayu Sarawak. Peluang semasa bertugas di luar pejabat, dieksploitasi sepenuhnya kerana dengan demikian sahaja yang dapat mengizinkan saya mendampingi masyarakat di Nanga Tiga. Perjalanan dengan perahu panjang dari Pekan Betong ke Nanga Tiga, mengambil masa selama lapan jam. Sepanjang perjalanan saya lebih banyak menyoal mengenai jenis-jenis pokok, akar-akar dan tumbuhan sepanjang sungai. Keunikan ini adalah kerana fauna dan floranya"
\end{abstract}

(halaman.94).

Peluang menikmati, bergaul dan berinteraksi dengan masyarakat Iban di Nanga Tiga semasa menjalankan tugas merupakan satu bonus dan rahmat yang paling besar kepada beliau dalam penciptaan novel ini. Beliau dapat merasai, menghayati dan menyelami laut fikiran, kejiwaan, corak dan budaya hidup masyarakat Iban dengan lebih mendalam sehingga ke dasarnya. Pengalaman menyelusuri sungai dan peluang mengenali jenis-jenis pokok dirakamkan beliau dalam GLHNT. Tambahan pula beliau selalu melawat ke rumah-rumah panjang ketika bertugas yang terletak di pedalaman. Menurut Jong Chian Lai (2007): 
"Ada ketikanya saya perlu menaiki perahu selama lapan jam, kemudian berjalan kaki selama empat jam untuk sampai ke rumah panjang tersebut. Ini pengalaman yang kaya, sangat menakjubkan, kadang-kadang mengejutkan, melalui satu suasana yang sangat berbeza dengan kehidupan saya. Minda saya ketika itu sangat kaya dengan pengetahuan suasana hutan begitu. Saya mengambil peluang ini untuk mencatatkannya dalam bentuk novel”

(halaman.19).

Pengalaman peribadi beliau meneroka kehidupan masyarakat Iban telah memudahkan beliau memindah dan menghadirkan segala bahan, maklumat, cebisan dan catatan-catatan tersebut dalam bentuk kreatif dan sekali gus menjadi rencah utama dalam aspek pembinaan teks GLHNT ini. Pengetahuan tentang pokok, burung, hutan dan haiwan dikayakan beliau dengan menyoal pemandu perahu panjang yang menghantar beliau ke rumah panjang. Situasi ini mengayakan lagi pengalaman beliau dalam menyelami dan mendekati kehidupan masyarakat Iban di rumah panjang sehingga terserlah dalam GLHNT. Sohaimi Abdul Aziz (1992) menegaskan bahawa pengarang menjadikan kehidupan masyarakat yang dilihat dan dirakamnya sebagai bahan mentah dalam penulisan kreatif. Sementara Rosnani Md Zain dan Nik Rafidah Nik Muhamad Affendi (2017) turut menegaskan bahawa sastera merupakan manifestasi daripada fenomena sosial yang wujud dalam masyarakat. Fenomena sosial yang terjadi dalam masyarakat inilah yang memberi idea kepada pengarang untuk menghasilkan kesusasteraan sama ada dalam bentuk cerpen, drama, novel mahupun puisi (hal.82). Rentetan itu, kehidupan masyarakat yang pelbagai bentuk dan ragam menjadi ilham pengarang untuk berkarya sebagaimana Jong merakamkan ragam kehidupan masyarakat Iban di Nanga Tiga. Ringkasnya, Jong tidak mensia-siakan pengalaman peribadi beliau, malahan mengoptimum dan menggunakan sumber ini sebagai inti pati dalam penciptaan novel ini. Beliau meletakkan empati yang tinggi dan menuangkannya dalam pengalaman peribadi beliau untuk membentuk tekstual yang sempurna dalam GLHNT.

\section{Kehadiran Struktur}

GLHNT yang dihasilkan pada tahun 1986, menghadirkan kepekaan diri pengarang terhadap nasib golongan etnik yang terpinggir daripada arus pembangunan. Oleh itu, pengarang menghadirkan struktur menerusi subjek-subjek, watak dan latar yang bersesuaian setelah membuat penyaringan dan pemilihan sewajarnya dalam pembentukan teks ini. Pengarang menghadirkan subjek penindasan terhadap golongan terpinggir, kepincangan masyarakat, dan kemunduran ekonomi. Subjek-subjek ini masih berlegar pada permasalahan semasa masyarakat di sesuatu tempat, khususnya Nanga Tiga. Subjek penindasan terhadap golongan terpinggir, iaitu etnik Iban oleh golongan kapitalis dipaparkan dengan jelas dalam novel ini. Keterpinggiran, kepincangan dan kemunduran ekonomi menyebabkan masyarakat ini mudah dieksploitasi dan dimanipulasi oleh pihak yang suka mengambil kesempatan seperti Tauke Yap. Tauke Yap merupakan golongan kapitalis merangkap opportunist yang mempunyai kuasa ekonomi dan melaksanakan pembalakan secara haram. Kerakusan golongan kapitalis menyebabkan masyarakat di Nanga Tiga jauh daripada arus pembangunan sehingga masyarakat tersebut digambarkan miskin, terpencil, tertutup dan daif. Pemerhatian beliau sebagai seorang Pegawai Pemasaran Lada Hitam yang ditugaskan di Sri Aman untuk memberikan ceramah, telah memberi peluang besar kepada beliau untuk berinteraksi dengan penduduk Nanga Tiga sehingga menyelami kisah hidup mereka yang sering ditindas dan dimanipulasi demi sedikit wang ringgit. Kisah kehidupan yang serba kekurangan inilah dirakamkan beliau dalam GLHNT.

Aspek struktur dalam novel ini turut memperlihatkan kehadiran watak penentang pembangunan sebagai utusan pengarang untuk menonjolkan idea, persepsi dan sikap beliau akibat perasaan bimbang dan marah kepada pihak yang mengeksploitasi masyarakat demi keuntungan sendiri. Jong Chian Lai (2000), menyatakan bahawa "Apa yang mahu ditonjolkan melalui novel ini adalah pancaran idea, persepsi dan sikap penulis tentang perasaan bimbang, ketakutan dan kemarahan masyarakat terhadap pihak yang mengeksploitasi mereka" (hlm.94). Justeru, beliau telah mencitra dan menghadirkan watak Jabau yang merupakan watak protagonis yang berubah menjadi antagonis apabila sanggup menentang ketua rumah panjang dan menentang rancangan pembalakan di Nanga Tiga. Watak Jabau merupakan wakil golongan terpinggir yang berjuang secara individu bagi mengekspresi kemarahan dan kebimbangan terhadap kegiatan pembalakan secara haram yang dijalankan Tauke Yap. Jabau rela berjuang seorang diri dalam mempertahankan bumi Nanga Tiga dan terkorban sebagai tragic hero. 
Pengarang menghadirkan peranan watak Jabau dengan berkesan dan menyentuh perasaan sebagai insan yang amat mencintai alam dan warisan bangsa. Kehadiran watak Jabau dalam GLHNT ini bertepatan dengan cita-cita pengarang untuk memberikan kesedaran kepada masyarakat tentang kualiti kehidupan agar tidak terus mundur daripada arus pembangunan. Pengarang menyalurkan aspirasi, visi dan harapannya menerusi watak Jabau yang rela berjuang membela bumi hijau Nanga Tiga yang menjadi medan perburuan dan sumber pendapatan penduduk di Nanga Tiga. Watak Jabau lebih rela mati dengan melanggar adat rumah panjang Nanga Tiga dengan membunuh golongan yang memanipulasi penduduk kampung demi perasaan cintanya dan kelangsungan hidup hutan hijau Nanga Tiga.

Pengalaman pengarang mengunjungi rumah-rumah panjang ketika menjalankan tugas rasmi sebagai Pegawai Pemasaran Lada Hitam membolehkan beliau menghadirkan latar tempat khasnya rumah panjang Nanga Tiga dengan terperinci. Beliau telah mengunjungi lebih daripada 100 buah rumah panjang semasa bertugas di Sri Aman. Beliau juga berpeluang bermalam di rumah panjang milik masyarakat Iban ketika bertugas. Kadang-kadang beliau tidur di bawah tengkorak yang digantung di ruai. Pengaruh penulisan beliau lebih kepada rakaman-rakaman minda semasa bertugas di luar stesen ke rumah panjang. Beliau melawat melebihi 100 buah rumah panjang di Bahagian Kedua melalui darat, sungai dan terpaksa berjalan kaki semasa tugas tersebut harus diselesaikan. Pengalaman begini yang banyak dimasukkan dalam hasil karya beliau. Pengalaman berharga ini dimanfaatkan beliau untuk merakam suasana, bentuk, dan ciri-ciri sebuah rumah panjang (Jong Chian Lai, 2000). Bagi beliau, seseorang penulis harus mengelak daripada menggunakan latar rumah panjang sekiranya tidak pernah berkunjung ke tempat itu. Oleh itu, rakaman sebuah rumah panjang amat rinci dan merupakan sebahagian besar latar tempat peristiwa-peristiwa yang berlaku dalam novel ini. GLHNT berlatarkan sebuah kawasan penempatan Iban di Bahagian Sri Aman iaitu Bahagian Kedua Sarawak iaitu tempat pengarang bertugas. Secara khususnya pula tempat yang menjadi pusat penceritaan ialah Nanga Tiga yang mengambil sempena nama Sungai Nanga Tiga iaitu cabang ketiga kepada sungai Batang Layar selain Nanga Satu dan Nanga Dua. Berikut ialah peta yang menunjukkan kedudukan Nanga Tiga di Betong.

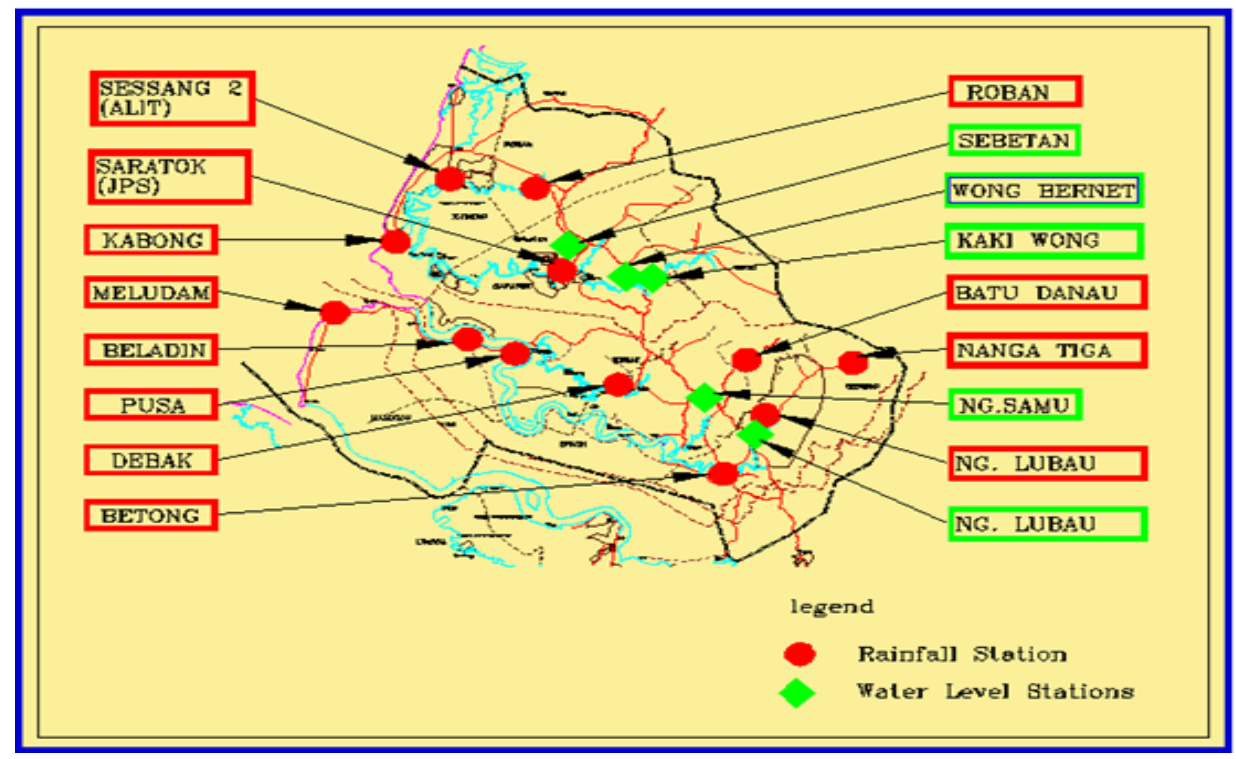

Rumah panjang Nanga Tiga merupakan kawasan terpencil dan jauh dari Pekan Betong iaitu kira-kira lapan jam menaiki perahu berenjin. Pengalaman menyampaikan ceramah tentang cara-cara meningkatkan hasil pertanian khasnya tanaman lada di rumah-rumah panjang memudahkan beliau melukiskan dengan rinci tentang lokasi dan bentuk rumah panjang termasuklah fungsi setiap ruang dalam rumah panjang. Rumah panjang Nanga Tiga dilukiskan mempunyai 30 pintu dengan penghuni kira-kira 253 orang. Rumah panjang sinonim dengan etnik Iban di Sarawak kerana kebanyakan mereka tinggal di kediaman tersebut. Latar lain yang dideskripsi pengarang hasil daripada pengalaman peribadi beliau dalam novel ini ialah hutan hijau Bukit Kaling di Nanga Tiga. Pengalaman menempuhi perjalanan selama empat jam dalam hutan sebelum sampai ke rumah panjang memberi kesempatan kepada beliau merakam suasana dalam hutan seperti yang dihadirkan dalam GLHNT. Hutan ini menjadi 
tempat berburu, menjebak dan menjerat binatang seperti babi hutan, kera, monyet, tupai dan lotong untuk mendapatkan makanan bagi masyarakat rumah panjang. Hutan ini kaya dengan alam flora yang menjadi sumber untuk mencari pucuk-pucuk kayu, sayur dan buah-buahan. utan inilah yang hendak dibalak Tauke Yap kerana hutan ini kaya dengan pokok-pokok berharga seperti ramin, embawang, meranti, empetir, keladan dan keruntum sehingga menimbulkan penentangan Jabau.

Ringkasnya, kehadiran aspek struktur seperti subjek atau persoalan, watak dan latar dalam bahagian ini dihadir dan digembleng pengarang dengan kemas dan padat dalam pembinaan teks ini. Subjek-subjek yang dihadirkan bersesuaian dengan pemikiran, latar dan watak yang dikemukakan pengarang berdasarkan pengalaman peribadi beliau. Watak yang bangkit menentang ketidakadilan menandakan gagasan pengarang dalam menyuarakan semangat untuk mempertahankan maruah dan warisan bangsa sehingga menjelmakan pemikiran yang hendak disampaikan pengarang. Kesemua aspek struktur mengukuhkan pembinaan teks ini sebagai karya yang lengkap dan bermutu sekali gus mencerminkan sifat jati diri dan misi pengarang dalam berkarya.

\section{Kehadiran Aliran}

Novel ini beraliran realisme. Realisme yang dibentangkan pengarang memperlihatkan sastera yang amat akrab hubungannya dengan sosial dan masyarakat. Tugas realisme adalah untuk menggambarkan masyarakat secara jelas dan memberi pendedahan terhadap peristiwa yang berlaku dalam kehidupan seharian. Perbincangan berfokus pada perekonomian, status dan stratifikasi masyarakat, politik dan pembentukan sosial. Mana Sikana (2006) menjelaskan bahawa "Aliran ini memfokuskan perjuangan masyarakat dan sastera dijadikan alat untuk mencapai matlamat dan menuntut pengarang bersifat protes sosial" (hlm. 44). Teks yang sebegini biasanya bersifat komited dan memperlihatkan hubungan sastera dengan masyarakat dan menepati tanggapan bahawa sastera adalah cerminan masyarakat. Pengarang pula mesti menjadi propagandis zaman dengan menyuarakan kesukaran dan kesusahan serta perjuangan masyarakat menerusi karyanya setelah pengarang menyelami sendiri situasi dan keadaannya. Jong Chian Lai dalam GLHNT menghadirkan realiti berhubung perjuangan golongan terpinggir menentang golongan yang berkuasa dalam bidang ekonomi. Pengarang menghadirkan perjuangan masyarakat subaltern melalui watak Jabau yang teguh mempertahankan warisan tradisi nenek moyang daripada dicerobohi. Perjuangan Jabau penuh dengan kesulitan dan kesukaran adalah realiti yang berlaku dalam masyarakat kerana dia hanya berjuang seorang diri memprotes pembalakan haram di Nanga Tiga. Walaupun perjuangan Jabau menemukan kegagalan namun dapat menyedarkan penduduk Nanga Tiga tentang kesilapan mereka menyetujui pembalakan tanpa memikirkan kesannya kepada alam sekitar. Aliran realisme yang dipegang pengarang dalam novel ini memperlihatkan kesesuaiannya dengan subjek-subjek dan pemikiran yang berhubung dengan perjuangan masyarakat dalam mempertahankan hak, warisan nenek moyang dan maruah bangsa sehingga teks ini dapat dianggap sebagai sebuah dokumentasi sosial. Sebuah teks dokumentasi sosial memanifestasikan pencerminan protes sosial yang dibawakan oleh pengarang dalam menangani perubahan dan pembangunan minda masyarakat.

Secara rangkumannya, GLHNT merupakan manifestasi sikap prihatin dan kepekaan pengarang terhadap masyarakat terpinggir di kawasan pedalaman dan menjadi sasaran eksploitasi dan manipulasi pihak yang mahu mengaut keuntungan dan mengambil kesempatan. Pengalaman-pengalaman ini disaring, dipilih dan disesuaikan sebelum dibaur dan dianyam dalam teks agar hasilnya lebih menarik dan efektif. Cebisan-cebisan pengalaman ini yang mencetuskan idea sehingga terhasilnya GLHNT. Pengarang menghadirkan subjek, menetapkan latar, melukiskan watak dan mengekspresikannya dengan gaya bahasa sekreatif mungkin serta menarik sehingga terserlah kekuatan dan penguasaan bahasa yang lancar, indah dan kreatif. Kehadiran pengalaman peribadi telah dicanai dan diramuankan dalam novel ini sehingga sebati sebagai sebuah teks yang bermutu manakala aliran realisme yang menjadi naratif penciptaan megukuhkan teks ini sebagai sebuah teks dokumentasi sosial yang berupaya memberikan kesedaran agar masyarakat membuat anjakan minda demi sebuah kemajuan.

\section{KEHADIRAN DALAM PEMBERONTAKAN}

Sifat berani dan bijaksana yang dimiliki pengarang sebagaimana yang dituntut dalam teori Teksdealisme merupakan faktor yang mendorong dan mewujudkan desakan sama ada dari dalam jiwa atau luaran serta rangsangan yang menggerakkan seseorang untuk berkarya (Mana Sikana, 1990). 
Pandangan ini menunjukkan bahawa pengarang turut mengutip pengalaman dan galakan berkarya melalui pelbagai saluran hasil desakan jiwa mereka. Dalam konteks Jong Chian Lai, beliau tidak berada ditakuk lama dengan menghadirkan idea menerusi usaha penyelidikan bagi menghasilkan karya yang lebih bermutu dan tidak lagi menggunakan saluran pengalaman peribadi sebagaimana dalam GLHNT. Seseorang pengarang yang melakukan penyelidikan akan mengumpul bahan dan fakta sebanyak yang mungkin. Pengarang kemudiannya menganalisis, memproses, menyaring dan menilai bahan atau fakta tersebut mengikut kesesuaian karya yang hendak dibentuk. Shahnon Ahmad (1994) menyimpulkan penyelidikan sebagai “... satu usaha yang sistematik untuk menerokai sesuatu gagasan melalui pengumpulan, penganalisisan dan perbahasan fakta-fakta secara kritis bagi memproses satu kesimpulan" (hlm. 72). Pandangan ini membuktikan yang penyelidikan bukan suatu yang mudah kerana menuntut kerja keras dan pemikiran kritis pengarang dalam memproses maklumat yang dikumpul. Dalam pembentukan teks, proses kreatif dan penyelidikan mempunyai hubungan yang erat. Hal ini demikian kerana melalui penyelidikan seseorang pengarang akan memperolehi pengalaman untuk dijadikan modal dan idea dalam penciptaan karya kreatifnya.

\section{Kehadiran Sumber Idea}

Pemberontakan memperlihatkan tindakan pengarang membuat rombakan dan pembaharuan dengan menghadirkan sumber pengalaman menerusi penyelidikan. Pengarang tidak lagi mengekalkan teknik dan narasi penciptaan terdahulu, iaitu menghadirkan sumber melalui pengalaman peribadi. Penyelidikan dilakukan dengan membuat pembacaan, pemerhatian, perenungan, penelitian dan kajian. Penyelidikan melalui pembacaan amat signifikan dalam membantu pengarang memperolehi fakta dan bahan yang bakal diproses. Menurut Shahnon Ahmad (1994) "Penyelidikan hanya membolehkan pengarang mendapatkan bahan mentah yang perlu diolah secara kreatif, diberi bentuk, dimaknakan melalui asosiasi yang pelbagai dan digubal menjadi pengalaman-pengalaman. Kemudian diciptakan watak yang hidup perwatakannya, digauli dengan latar suasana yang berfungsi malah perlu disiratkan makna-makna pengalaman itu dalam satu corak texture yang indah berseni dan menuntut daya imaginasi yang tinggi untuk merasai pengalaman itu" (hlm. 181). Pandangan ini menyuguhkan bahawa penyelidikan memberikan pengalaman kepada pengarang untuk mencipta teks dan pengarang perlu menggunakan daya kreativiti, imaginasi, intuisi serta halusinasi untuk mengolah dan menggaul serta membaur elemen-elemen struktur yang membentuk teks agar teks tersebut memberi kesan apabila dikhalayakkan.

Setelah mendapat kepuasan berkarya berdasarkan pengalaman peribadi dalam tiga buah novel terawal, Jong bergerak secara sedar untuk melakukan penyelidikan dengan hasrat karya yang dihasilkan lebih bermutu. Hasrat ini bertepatan dengan kehendak Teksdealisme yang menuntut pengarang sentiasa mencari pembaharuan dalam berkarya agar dapat menghasilkan karya yang unggul. Novel Pemberontakan merupakan karya yang terhasil daripada proses penyelidikan yang dilakukan Jong dengan penuh ketelitian dan ketekunan. Jong Chian Lai (2000) menyatakan bahawa "Teknik penulisan novel mula berubah daripada pengalaman peribadi mengorak langkah pula dalam bentuk penyelidikan. Dengan demikian saya perlu banyak membaca buku-buku yang ada hubungan untuk memperkaya ilmu bantu" (hlm.98). Tambahan pula ada suara-suara yang mencabar beliau supaya keluar dari kepompong Ibanisme. Walaupun beliau telah berjaya menghasilkan tiga buah novel, iaitu Gugurnya Langit Hijau Nanga Tiga, Pindah dan Buaya Putih Buaya Kudung namun masih berlaku krisis dalaman antara kepuasan dan rasa tidak puas. Oleh itu, beliau mahu mencuba teori yang lain. Beliau banyak membaca novel-novel Barat yang disyorkan oleh rakan penulis mapan ketika itu. Antara novel yang dibaca beliau ialah Cahaya Ogos (Light in August) karya William Faulkner yang diterjemah oleh Shamsudin Jaafar, novel Madu dalam Saringan (Nectar in a Sieve) karya Kemala Markandaya, terjemahan oleh Mokhtar Ahmad dan novel Perjuangan Sia-Sia (In Dubious Battle) karya John Steinbeck, yang diterjemah oleh Muhammad Ridhwan. Setelah membaca novel-novel tersebut beliau bertekad untuk menghasilkan novel yang lebih baik daripada sebelumnya. Justeru, beliau mencuba metode penyelidikan selepas membaca novel-novel Barat itu. Tambahan pula, rangsangan penghasilan novel Pemberontakan adalah disebabkan rasa ego beliau sendiri untuk menjadi penulis pertama di Bumi Kenyalang yang menghasilkan novel sejarah berbentuk kreatif. Pada peringkat awalnya Jong mengalami kesukaran untuk memulakan novel ini. Novel-novel awal tidak begitu menyukarkan kerana merupakan pengalaman peribadi. Penghasilan Pemberontakan memerlukan komitmen yang tinggi. Jong Chian Lai 
(2000) menyatakan bahawa "Tiga buah novel yang dihasilkan terdahulu tidak menyukarkan kerana itu merupakan pengalaman peribadi. Pemberontakan ialah satu peristiwa sejarah yang berlaku di Sarawak. Banyak analisis, menungan, penelitian dan kerja yang dilakukan supaya fakta sejarah itu dikekalkan" (hlm.96).

Novel Pemberontakan adalah bersumberkan sejarah yang berlaku di Sarawak. Asas kepada idea menulis novel itu adalah dari Sarawak Government Almanac. Di belakang almanak ini terdapat peristiwa-peristiwa bersejarah yang berlaku mulai dari Kesultanan Brunei Darussalam sehingga pemerintahan keluarga Brooke. Di belakang almanak tersebut terdapat juga kronologi sejarah Sarawak dari 15 Ogos 1839, James Brooke melawat Sarawak dengan kapal layar Royalist sehingga pada 20 Februari 1857 iaitu pemberontakan orang-orang Cina di Kuching. Tempoh selama 16 tahun dimuatkan dalam novel setebal 519 halaman ini. Peristiwa-peristiwa sejarah inilah yang diproses, diolah, dijalin, disaring, ditokok tambah secara kreatif dan dibaur dengan daya imaginasi dan kreativiti sehingga terhasilnya Pemberontakan (1994). Dalam usaha mendapatkan fakta-fakta sejarah, beliau telah melakukan penyelidikan melalui pembacaan. Jong Chian Lai menyatakan bahawa banyak tugas yang dilakukan daripada pembacaan buku sejarah yang ditulis oleh penulis Barat yang mungkin menyimpang. Beliau memperolehi banyak fakta-fakta, latar, insiden berlaku, watak perwatakan dan pelbagai bahan dalam buku-buku (Zuriyah Jemi, 2003)). Fakta-fakta sejarah dikutip beliau hasil dari pembacaan terhadap buku seperti My Life in Sarawak (Margaret Brooke), Adventures Among The Dayaks of Borneo (Frederick Boyle), The White Rajah's of Sarawak (Robert Payne), Glimpse from the Sarawak Past (Joan Lo), Kuching in Pictures 1840-1960 (Ho Ah Choon), Natives of Sarawak (Evelyn Hung) dan Nine Dayak Nights (W.R Geddes).

Setelah memperolehi fakta-fakta sejarah, beliau mengalami dilema sama ada mahu berpihak kepada penulis Barat atau mempunyai pendirian peribadi. Namun, beliau membiarkan cerita dalam novel itu menyelesaikannya secara tidak langsung. Pembacaan dan kutipan terhadap fakta-fakta sejarah menyebabkan pemikiran beliau sarat dengan begitu banyak fakta. Beliau mengalami kesukaran untuk memilih fakta yang lebih penting kerana setiap fakta ada hubungannya. Di sinilah pengarang berperanan dengan bijaksana untuk memilih, menyaring dan menilai fakta-fakta yang ada seperti yang disarankan dalam teori Teksdealisme iaitu pengalaman-pengalaman yang diperolehi daripada pelbagai sumber perlu dibuat penyaringan dan penapisan. Menurut Laporan Panel Penilai Hadiah Novel ESSOGAPENA 1, kekuatan novel ini terserlah pada ketelitian pengarang mengenai fakta sejarah berdasarkan penyelidikan yang luas dan perlukisan latar dan perwatakan yang memperlihatkan keprihatinan pengarang (Jong Chian Lai, 2000). Jeniri Amir (2007) turut mengakui kekuatan Jong membuat penyelidikan dengan menyatakan bahawa "Salah satu kekuatan Jong ialah kesungguhannya menyelidik persoalan yang hendak dituangkan ke dalam karyanya. Buktinya ialah bagaimana Jong mengadunkan maklumat pelbagai sumber sejarah sehingga lahirnya novel Pemberontakan yang menguji daya kepengarangannya" (hlm. 29).

Jong Chian Lai telah menghasilkan novel ini dengan menghadirkan sumber dan peristiwaperistiwa sejarah yang berlaku di Sarawak sebagai bahan kreatifnya. Bahan sejarah tersebut ialah sejarah pemberontakan kaum Cina di Sarawak pada 18 Februari 1857. Pada tarikh ini telah terjadi satu pemberontakan oleh kaum Cina terhadap pihak Inggeris. James Brooke yang menjadi teraju pentadbiran Inggeris di Kepulauan Borneo menjadi sasaran utama pemberontakan ini. Dalam sejarah pemberontakan ini, pada 18 Februari 1857, orang Cina yang terdiri daripada pelombong emas dan diketuai seorang Cina yang berketurunan Hakka telah mengumpul orangnya seramai 600 orang dan lengkap dengan senjata serta perahu menghilir sungai Sarawak menuju ke Kuching. Mereka telah menyerang kota James Brooke dan memusnahkan tempat kediaman pegawai-pegawai Inggeris. Pemberontakan ini telah berjaya membunuh Nicholetts yang disangkanya James Brooke. Dalam serangan ini James Brooke berjaya melarikan diri dengan berjalan kaki sehingga ke kuala Sungai Siol (Buyong Adil, 1981). Peristiwa dan fakta sejarah inilah yang menjadi sumber utama dalam membentuk dan menghamparkan daya kreativiti pengarang dalam penghasilan novel ini.

\section{Kehadiran Struktur}

Saranan Teksdealisme berdasarkan prinsip kehadiran dalam Pemberontakan (1994) dapat ditelusuri menerusi kehadiran subjek dan watak yang digembleng pengarang berdasarkan penyelidikannya. Menurut Jong Chian Lai (2000) “... semasa menulis novel ini, saya cuba menjaga keharmonian 
hubungan antara kaum yang sememangnya amat didukung oleh masyarakat kita" (hlm. 97). Berdasarkan penyelidikan beliau, subjek perpaduan dan keharmonian amat penting demi keamanan dan kesejahteraan masyarakat dan dapat mengelak sentimen perkauman. Oleh itu, dalam novel ini beliau menghadirkan subjek perpaduan dan keharmonian dengan memperlihatkan kesedaran kaum Cina dalam mempertahankan ketuanan peribumi Melayu dengan tidak mahu bermusuhan dengan orang Melayu. Perkara ini dapat dibuktikan melalui kata-kata Penghulu Sidek:

\begin{abstract}
“Aku cukup yakin orang Cina itu tidak bermusuh dengan kami. Tauke Tong pernah berkata demikian. Aku sanggup menggadaikan tanahku untuk mendapatkan senjata. Tetapi dia menolak bulat-bulat. Katanya, tidak perlu kedua-dua bangsa ini berbunuhan, kerana bangsa Cina terhutang budi dengan orang Melayu"
\end{abstract}

(Jong Chian Lai, 1994, halaman. 402).

Sehubungan itu, subjek ekonomi merupakan sebab utama penentangan kaum Cina kerana Inggeris telah menyekat kebebasan dan keuntungan ekonomi mereka. Inggeris telah memonopoli ekonomi dengan cuba mengambil alih kawasan perlombongan emas seperti yang dilakukan terhadap lombong antimoni. Ekoran itu, Jong Chian Lai turut menghadirkan subjek kepincangan masyarakat, iaitu dengan menghadirkan kelemahan dan kepincangan dalam masyarakat Melayu, Cina dan Iban akibat tekanan daripada penjajah. Setiap perjuangan pasti ada halangan dan kesukarannya dalam sejarah negara-negara yang dijajah dan hadirnya manusia yang menjadi pembelot bangsa dan tanah air. Dalam novel ini, orang Melayu digambarkan sebagai masyarakat yang mudah dibeli penjajah. Ramai yang menjadi 'anjing penjajah' dan berkhidmat sebagai askar Inggeris. Menurut Hazami Jahari (2007) "Makna di sebalik kisah sejarah dalam Pemberontakan ialah kesetiaan kepada bangsa dan negara adalah amat penting untuk kekuatan bangsa dan negara itu sendiri. Perjuangan tidak akan terhasil jika ada yang belot dan sanggup melihat bangsa sendiri tertindas" (hlm. 5). Pembelotan orang Melayu terhadap bangsanya sendiri menyebabkan perpecahan. Dalam kalangan orang Cina juga digambarkan adanya pembelot yang mahu memecah belah pelombong seperti Ular Emas dan orang-orangnya. Orang Iban pula sentiasa bermusuhan sesama sendiri sehingga melemahkan perpaduan mereka. Subjek politik turut dihadirkan pengarang melalui novel ini hasil daripada penyelidikan beliau terhadap buku-buku sejarah yang berkaitan dengan pemerintahan Inggeris di Kepulauan Borneo. Penggarapan permasalahan politik oleh pengarang pada zaman penjajahan Brooke memberikan pendedahan dan pengetahuan kepada khalayak tentang corak pentadbiran Tuan sebagai pemerintah yang tidak mampu untuk mentadbir dengan baik kerana mendapat tentangan daripada kaum peribumi seperti Iban dan Melayu serta kaum pendatang, iaitu orang Cina. Kemuncak penentangan terhadap pentadbiran Tuan di Kepulauan Borneo adalah tercetusnya pemberontakan oleh orang Cina yang memusnahkan Royalist dan kubu Tuan.

Hasil daripada penyelidikan secara perenungan dan penelitian terhadap wajah Tuan Brooke dan Rentap di Muzium Sarawak selain pembacaan terhadap buku-buku sejarah, maka Jong berjaya menghadirkan watak-watak ini dalam novel Pemberontakan. Jong Chian Lai (2006) menyatakan:

Terlintas dalam ruang fikiran bagaimana menginkarnasi watak-watak tersebut? Sewaktu menatap wajah Tuan dan Rentap di Muzium Sarawak, hampir sejam saya cuba meneliti/mentafsir/menganalisis untuk menterjemahkan perwatakan mereka dalam novel itu. Pada mulanya memang sukar untuk menggambarkan pakaian Inggeris, Cina dan Melayu waktu itu

(halaman. 97).

Penelitian dan penganalisisan Jong terhadap sumber rujukan tersebut mendorong dan memudahkan beliau menghadirkan watak-watak tersebut dan memerikan perwatakannya secara terperinci. Berdasarkan Teksdealisme, sumber rujukan adalah pelbagai dan terpulang kepada pengarang untuk memilih dan menilai sumber tersebut dalam usaha mengunggulkan teks yang dicipta. Pengalaman yang diperoleh melalui penyelidikan secara pembacaan, perenungan dan penelitian yang dibuat telah mendorong Jong menghadirkan watak Rentap, Tuan, Ketua Yong Seng dan Penghulu Sidek yang relevan dengan peristiwa bersejarah di Kepulauan Borneo. Jong Chian Lai menghadirkan watak Tuan yang sesungguhnya menjadi pemerintah di Sarawak semasa menjajah mulai pada tahun 1841 . Tuan 
dalam novel ini ialah ketua pentadbir Inggeris di Kepulauan Borneo. Hasil daripada ketekunan menjalankan penyelidikan melalui pembacaan seperti buku The White Rajahs of Sarawak dan membuat perenungan, Jong berjaya menyelami isi hati dan sifat-sifat Tuan sebagai pentadbir pada zaman itu. Tuan amat berhati-hati dalam tindakannya terhadap orang Melayu. Hal ini disebabkan oleh keperluan menjaga hati kaum peribumi ini agar tidak tersinggung dan dapat menerima pemerintahan yang cuba dibawa olehnya (Hazami Jahari, 2007). Tuan bertindak demikian kerana Tuan melihat orang Melayu sebagai bangsa yang tenang, peramah, boleh dipercayai dan pemurah. Sikap-sikap positif orang Melayu membuatkan Tuan risau kerana dalam ketenangan itu mungkin ada muslihat. Misalnya Tuan mengatakan "Ketenangan mereka membuat aku risau" (Jong Chian Lai, 1994, hlm16). Perkara yang paling merisaukan Tuan tentang orang Melayu ialah semangat mereka yang kental.

Selain itu, perenungan terhadap wajah patung Rentap dan ditambah dengan pembacaan terhadap buku Nine Dayak Nights, maka Jong dapat menyelami sikap dan kehidupan masyarakat Dayak dengan mengutarakannya melalui watak Rentap. Watak Rentap merupakan ketua kaum Iban yang amat berpengaruh dan pahlawan yang amat disegani masyarakat Iban. Rentap sering melancarkan kekacauan dan serangan. Rentap merupakan musuh utama Tuan dalam sejarah penentangan orang Iban. Misalnya Arthur Gregory menyatakan "Hanya Rentap menjadi musuh utama kita. Tapi Rentap sendiri ada musuhnya" (Jong Chian Lain, 1994, hlm.144). Pengarang hanya mendeskripsikan watak Rentap secara umum melalui kotak fikiran Tuan. Contohnya, "Dalam kotak fikirannya terbayang bagaimana tangkasnya pahlawan Iban: lebih gagah daripada askar kulit hitam dari Hindia Timur itu; menjunjung parang, menghunjam sangkuh, menyumpit dengan buluh runcing beracun-segala-galanya sudah dilalui Tuan (Jong Chian Lai, 1994, hlm. 143-144). Rentap digambarkan berani mencabar Tuan walaupun tidak pernah datang bersua muka dengan Tuan. Ketua Yong Seng merupakan watak yang menjadi ketua orang Cina di kawasan lombong. Ketua Yong Seng ialah jelmaan watak ketua pemberontakan kaum Cina pada 18 Februari 1857 dan seorang yang berketurunan Hakka. Kekuatan daya imaginasi dan kreativiti serta ditokok dengan pengalaman yang dikutip melalui penyelidikan, Jong berjaya menghadirkan watak Ketua Yong Seng seperti berikut:

Berpeluh muka Ketua Yong Seng. Berkilat muka berminyak itu disinari matahari pagi yang semakin terik. Dahinya yang melebar ke tengah kepala, di situ rambutnya kemas dipilin dan ditocang hujungnya, mengingatkan mereka tentang orang Cina yang kaya di Negeri Tembok Besar. Ketua Yong Seng sudah menampakkan gayanya seperti orang kaya

(Jong Chian Lai, 1994, hlm. 177)

Ketua Yong Seng amat mendendami Tuan kerana menghinanya dalam Groove di hadapan ketua-ketua kaum. Ketua Yong Seng amat gembira sekiranya orang Melayu menentang Tuan. Dendam ini cuba dilunaskan dengan merancang dan memimpin pemberontakan terhadap Tuan. Hasil daripada penyelidikan Jong tentang gambaran masyarakat Melayu pada zaman penjajahan Brooke, Jong berjaya menghadirkan fizikal dan pakaian Penghulu Sidek. Pengarang melakarkan fizikal dan pakaian Penghulu Sidek seperti berikut:

Dia berbaju Melayu warna merah muda. Mukanya bulat. Dahinya tidak lebar tapi licin. Gondol sedikit di bahagian atas dahinya, dan meninggalkan sedikit rambut di situ. Janggutnya seperti baru dicukur. Kebiasannya dia mengguntingnya tetapi semenjak tauke Cina itu lebih mendampinginya dia mendapat pisau cukur. Misainya tebal melindungi bibir atas.

(Jong Chian Lai, 1994, hlm. 49)

\section{Kehadiran Aliran}

Jong Chian Lai masih mengekalkan aliran penciptaannya dalam Pemberontakan menerusi naratif penciptaannya, iaitu aliran realisme. Pengarang yang menggunakan aliran ini dengan signifikan ialah Usman Awang dan Kala Dewata. Menurut Mana Sikana (2006) "Usman Awang adalah salah seorang pelopornya bersama Kala Dewata" (hlm. 44). Realisme sebenarnya memberikan refleksi kepada gaya yang terlihat menerusi karya-karya itu sendiri dan memperlihatkan kecenderungan melukiskan 
kebenaran dengan terperinci supaya nampak real atau benar. Safian Hussain, Mohd Thani Ahmad, Zakaria Ariffin, Ahmad Kamal Abdullah \& Suhaimi Muhamad (1988) menyimpulkan bahawa "Hakikatnya realisme lahir daripada pengalaman individu dan pengalaman menjadi punca yang menemukan kebenaran" (hlm.278). Berdasarkan aliran realisme, peristiwa yang dipaparkan mestilah yang benar berlaku dan bersejarah, namun yang dipentingkan ialah cara penyampaian dan pengalamannya diterima oleh manusia yang lain. Novel Pemberontakan merupakan novel yang menggambarkan realiti perjuangan masyarakat menentang penjajah dalam sejarah penjajahan Brooke di Sarawak khasnya pemberontakan yang dilakukan kaum Cina pada 18 Februari 1857. Semangat perjuangan orang Cina, Melayu dan Iban yang berbeza dalam novel ini digambarkan dengan terperinci oleh pengarang berserta suka duka dan halangan yang dihadapi mereka. Peristiwa penentangan ini sesungguhnya berlaku dalam sejarah Sarawak dan usaha pengarang dalam memartabatkan peristiwa dan fakta sejarah adalah bertepatan dengan saranan aliran realisme yang karya sastera adalah cerminan masyarakat. Pengarang memperlihatkan perjuangan sebenar masyarakat yang ditindas penjajah. Jong Chian Lai telah berjaya merakam dan menyulam peristiwa-peristiwa penentangan dengan teliti dan kemas berdasarkan pengalaman yang dikutip beliau melalui penyelidikan terhadap buku-buku sejarah. Aliran yang dikejapkan pengarang dalam pembinaan novel ini menggambarkan secara serius penentangan dan perjuangan masyarakat subaltern yang terpinggir dalam menentang penjajah yang berkuasa dan menindas golongan bawahan atau golongan yang dijajah. Mata pena Jong mencorakkan minda masyarakat agar bangun dan bangkit untuk membela maruah bangsa dan tanah air agar tidak berterusan menderita.

Secara rangkumannya, Pemberontakan lahir hasil daripada sumber penyelidikan, pembacaan, pemerhatian dan rujukan Jong terhadap sumber, peristiwa dan fakta sejarah yang berlaku di Kepulauan Borneo pada zaman penjajahan Brooke. Tekstual teks yang dibentuk oleh struktur yang padat setelah penyaringan dan penaakulan terhadap bahan sumber menjadikan idea dan pemikiran dalam novel ini mantap dan berupaya mencitrakan misi nasional pengarang untuk penyatuan bangsa. Aliran realisme yang dipaparkan menerusi perjuangan tiga kaum dalam menentang penjajah dalam novel ini berupaya mencerminkan sifat jati diri untuk menanam kesedaran demi mengangkat maruah bangsa.

\section{KEHADIRAN DALAM ENSERA MARGA TIMUR DARI ST ANTHONY}

EMTSA merupakan sebuah lagi karya yang terhasil daripada pengalaman melalui penyelidikan. Walau bagaimanapun, penyelidikan yang dilakukan Jong merentas pelbagai disiplin ilmu sehingga menggali ke dasar marin arkeologi, sejarah, geografi, lagenda, hikayat, kepercayaan, adat, feminisme, magis dan mitos masyarakat yang menjadi fokus penciptaan. Novel ini terhasil daripada sumber pembacaan beliau terhadap novel One Hundred Years of Solitude (OHYOS) atau Sumpah Tujuh Keturunan (terjemahan) karya novelis tersohor Amerika Latin, iaitu Gabriel Garcia Marquez. Hasil daripada pembacaan terhadap novel ini, beliau mencipta ceritanya sendiri dan lahirlah novel EMTSA. Berhubung dengan peranan dan kesan pembacaan atas kreativiti, A. Samad Said (1987) menyatakan bahawa "... melalui pembacaan, dapat mendorong seseorang pengarang memikir ceritanya sendiri. Tegasnya setelah membaca beberapa buah novel serta mengetahui jalan ceritanya dengan mudah seseorang penulis memikirkan beberapa cerita yang boleh dibentuknya sendiri" (hlm.24). Pandangan ini menjelaskan bahawa pembacaan yang dilakukan pengarang menyumbangkan sumber pengalaman yang dapat mencetuskan idea untuk membentuk dan mencipta karyanya dengan cara tersendiri. Walaupun Pemberontakan (1994) dan EMTSA (2009) berdasarkan sumber penyelidikan, namun dimensi, fokus, aliran dan teknik penceritaannya amat berbeza. Sumber penyelidikan dalam EMTSA lebih luas dan menyeluruh berbanding Pemberontakan (1994) sehingga menyerlahkan novel ini sebagai sebuah novel pascamodenisme.

\section{Kehadiran Sumber Idea}

Pembacaan Jong Chian Lai terhadap novel OHYOS mempengaruhi penciptaan beliau dalam EMTSA ini. OHYOS merupakan sebuah fiksyen ciptaan Gabriel Garcia Marquez yang membawa aliran realisme magis. Novel ini diterbitkan di Buenos Aires pada tahun 1967 dan telah menggempar dan menggegarkan dunia sastera di Barat. Ungku Maimunah Mohd. Tahir (1996) menyatakan: 
Novel tersebut dianggap sebagai sebuah total novel, sebuah karya terbesar yang pernah terhasil dari bumi Amerika Latin dan merupakan karya agung abad ke-20 ini, dan merupakan karya yang paling banyak diperkatakan dalam seluruh kesusasteraan Amerika Latin. Lebih dari itu OHYOS dianggap sebagai kemuncak sumbangan Garcia kepada bentuk realisme magis

(halaman.22).

OHYOS merupakan sebuah novel yang memparodikan sejarah Colombia, iaitu peristiwa berdarah yang dikenali sebagai 'Pembunuhan Beramai-ramai Cienaga' 1928 yang berlaku di Santa Maria Colombia. Sohaimi Abdul Aziz (2002) menyatakan bahawa "Unsur sejarah yang telah dibawa masuk oleh Marquez ke dalam OHYOS telah melalui proses dikanonisasi iaitu ia telah diputarbelitkan, ditokoktambahkan dan difiksikan. Proses dikanonisasi dilakukan melalui teknik parodi ironik. Peristiwa Pembunuhan Beramai-ramai Cienaga 1928 telah diparodi dan diironikkan dalam OHYOS" (hlm.148). Pandangan ini jelas membuktikan bahawa OHYOS merupakan sebuah karya metafiksyen historiografik kerana sudah diparodikan dengan teknik parodi ironik iaitu teknik yang digunakan untuk mengaburkan hubungan sejarah dan fiksyen dengan mendekonstruksikan sumber lama dan melahirkan sesuatu yang berkontradik di samping menyindir secara halus. Sohaimi Abdul Aziz (2002) menegaskan bahawa "Metafiksyen historiografik merujuk kepada simulakrum iaitu salinan yang sempurna yang tidak mempunyai sumber asal dan kesimulakrumnya itu jelas apabila unsur sejarah yang dibawa masuk itu telah diputarbelitkan, ditokok tambah dan difiksikan. Justeru, sudah tidak ada lagi hubungan dengan sumber asal" (hlm.147). Pandangan ini mengintepretasikan bahawa pengarang membuat suatu pemberontakan dan pembaharuan termasuk menjungkarbalikkan fakta sejarah secara besar-besaran dalam usaha menghasilkan sesuatu yang baharu untuk renungan dan tatapan khalayak dunia.

EMTSA merupakan sebuah karya metafiksyen historiografik kerana pengarang telah memfiksi dan memutarbalikkan unsur dan fakta sejarah sebenar tentang Rentap semasa penjajahan James Brooke di Sarawak. Novel ini mengambil latar tahun 1800-an iaitu setelah pemerintahan James Brooke sehinggalah selepas merdeka. Berdasarkan sejarah penjajahan Brooke di Sarawak, Rentap merupakan penentang yang hebat kerana beberapa kali serangan yang dilancarkan Inggeris gagal menawan Rentap. Serangan pertama pada bulan Jun 1857 di Bukit Sadok yang merupakan kubu kuat Rentap telah gagal. Begitu juga dengan serangan kedua pada tahun 1858 yang turut membawa kegagalan kepada pihak Inggeris. Namun dalam serangan kali ketiga pada 28 Oktober 1861, pihak Inggeris telah berjaya mengalahkan Rentap kerana kesilapan Rentap sehingga hilang ramai pengikutnya. Rentap berjaya melarikan diri ke ulu Sungai Entabai sehinggalah meninggal dunia (Buyong Adil, 1981). Peristiwa sejarah tentang Rentap inilah yang menjadi idea penciptaan dalam EMTSA tetapi telah difiksi dan dijungkar balik oleh Jong dengan mengangkat Rentap sebagai pahlawan yang hebat dan dikatakan tidak dapat dikalahkan Inggeris sebaliknya Rentap yang menjadi penjajah sehingga Inggeris tunduk kepadanya dan menuruti semua kemahuan Rentap. Rentap dalam EMTSA ditampilkan pengarang dengan aksi dan sikap yang baharu dan tidak menentang Inggeris dengan kekerasan. Unsur sejarah sebenar telah diselewengkan pengarang kerana dalam sejarah, setelah serangan kali ketiga Rentap telah kalah dan berundur. Berdasarkan sejarah, Rentap sering menentang Inggeris dengan kekerasan dan pemberontakan bukannya dengan kuasa minda, kuasa magis dan kebijaksanaan seperti yang dibentuk dan difiksikan oleh pengarang dalam EMTSA. Rentap telah membuat transformasi minda demi kemajuan bangsanya walaupun mendapat tentangan hebat daripada masyarakat Iban.

Sehubungan itu, dalam usaha menghadir dan memantapkan sumber idea, Jong Chian Lai merujuk buku-buku lain dalam proses menghasilkan EMTSA seperti Arkeologi Prasejarah Satu Pengenalan Ringkas terjemahan Shakila Yaacob yang ditulis oleh Frank dan Robert (1990), Asas Ukiran Iban: Satu Pengenalan oleh Augustine Anggat Ganjing (1991) dan cerita-cerita lagenda kaum Iban iaitu Hikayat Keling Gerasi Nading oleh Jimmy Donald (1998). Sumber-sumber rujukan inilah yang digembleng sebagai rencah dan ramuan kemas dalam EMTSA sebagai sumber idea. Tindakan beliau ini selari dengan saranan Teksdealisme yang menuntut pengarang mendapatkan pengalaman sebanyak mungkin dan daripada pelbagai sumber. Beliau telah banyak melakukan penelaahan dan penyelidikan dalam penghasilan karya ini termasuklah penelaahan terhadap folklore masyarakat Iban sehingga mengheret beliau memanjat tangga aliran realisme magis. Novel ini juga merupakan karya Jong yang memperlihatkan ciri pembaharuan dengan pelbagai teknik dan tidak berplot. Panel Penilai 
Hadiah Sastera Kreatif Budaya Sarawak 2003/2005 menyifatkan novel ini tidak mempunyai pembahagian bab. Episod-episod dicantum-cantum tanpa susunan seolah-olah tidak berplot. Novel ini juga sarat dengan pelbagai teknik, unsur budaya, ritual, mitos dan kepercayaan. Pengarang menyelitkan unsur-unsur sejarah dan imaginasi untuk mengangkat Rentap sebagai tokoh lagenda ternama di Sarawak. Penceritaan dalam novel ini tidak memberi fokus kepada watak tetapi lebih kepada peristiwa manakala bahasa pula agak menarik dan banyak menggunakan bahasa Iban. Komen tersebut memperlihatkan pembaharuan yang dilakukan oleh Jong dalam penciptaan EMTSA.

\section{Kehadiran Struktur}

Pengarang menghadirkan aspek struktur dari segi subjek, latar dan watak yang memperlihatkan pembaharuan dalam EMTSA. Subjek yang dihadirkan lebih menyeluruh dan mencakupi pelbagai bidang seperti politik, feminisme, pengorbanan, penentangan, penindasan, ekonomi, perlanggaran adat, penjajahan baharu, budaya, politik, kebijaksanaan, feminisme, emansipasi wanita, kuasa magis dan marin arkeologis. Subjek-subjek yang dihadirkan dalam teks ini lebih holistik, komprehensif dan bervariasi. Tindakan ini menunjukkan Jong Chian Lai telah melakukan pemberontakan melalui pembaharuan yang dilakukannya dalam membentuk teks ciptaannya. Beliau tidak lagi berada di takuk lama, sebaliknya mengorak langkah dengan melonjakkan teks ciptaannya ke dunia pascamodenisme. Subjek-subjek, watak dan latar dalam EMTSA menggambarkan bangsa Timur yang mempunyai kuasa untuk maju dan mengecapi pembangunan walaupun pada era 1800-an. Oleh itu, pengarang telah meletakkan pahlawan Iban sebagai pejuang yang berupaya mengalahkan pemerintahan Tuan Brooke di Kepulauan Borneo dengan adanya kekuasaan yang disalurkan melalui kuasa magis, kuasa minda dan keajaiban yang dimiliki Rentap. Tuan digambarkan tunduk dan mengikut kemahuan Rentap bagi mengelakkan bangsa Barat mendapat malu. Pembalikan fakta sejarah oleh Jong telah mengangkat karya ini dan meletakkan dirinya dalam landasan karya-karya pascamodenisme. Perbincangan aspek struktur dalam teks ini seterusnya diperlihatkan dalam huraian aliran realisme magis EMTSA yang menjadi narasi penciptaannya setelah secara sedar atau sebaliknya membaharui aliran penciptaannya. Jong tidak lagi mengekalkan aliran realisme sebagaimana dalam dua buah novel terdahulu.

\section{Kehadiran Aliran}

EMTSA merupakan rekaan Jong Chian Lai khas buat khalayak yang mahu berfikir tentang persoalan yang hendak disampaikan. Pengarang menggunakan aliran realisme magis sebagai narasi penciptaannya. Pembaharuan dan pemberontakan terhadap anutan aliran ini menunjukkan Jong Chian Lai sentiasa berusaha untuk meningkatkan pencapaiannya untuk mencapai tahap keunggulan. EMTSA sudah meninggalkan aliran realisme yang dianutinya dalam kedua-dua novel sebelum ini. Novel ini merupakan cereka mimpi, halusinasi, cereka beralasan dan fantasi dalam dunia real dan unreal yang dibaurkan pengarang dalam menyampaikan idea dan gagasannya. Realisme magis merujuk kepada gaya estetika dalam sastera, iaitu elemen magik dicampur aduk dalam alam realiti bagi memahami makna realiti dengan mendalam. Elemen magis mempersembahkan kejadian-kejadian biasa tetapi menghalalkan pemikiran realiti dan fantasi. Bermakna aliran realisme magis membaurkan dunia realiti, fantasi, magik dalam satu pemikiran. Secara rincinya, realisme magis adalah cantuman dua kata iaitu realism dan magic. Realisme asalnya adalah satu aliran yang dianuti oleh satu gerakan sastera bermula awal abad ke-19. Aliran ini diaplikasikan kepada prosa yang memaparkan ilusi kehidupan yang mencakupi persekitaran yang para watak dan segala keperihalan yang realistik iaitu yang munasabah. Magic pula merujuk pada jalinan unsur-unsur fantasi, mitos dan legenda. Dalam konteks mitos dan lagenda inilah banyak dongengan dengan cerita pari-pari, manusia boleh terbang, kematian dan tragedi yang menakjubkan dan makhluk-makhluk yang di luar alam nyata. Dalam karya yang beraliran realisme magis, unsur supernatural juga digabungkan sehingga penampilan keluarbiasaan ketara sekali. Menurut Shahnon Ahmad (2002) "Langgam penceritaan digembar-gemburkan, dilebih-lebihkan sehingga lebih fantasi, lebih sensasi dan karutnya menyimpang dari dunia nyata. Gabungan realism dan magic inilah lahirnya aliran realisme magis" (hlm.131). Aliran ini menggariskan ciri-ciri seperti hubungan sebab musabab yang kurang ditaati, peristiwa ke peristiwa jelas namun ada unsur remang, peristiwa masa kini bertindih dengan masa silam, adanya hubungan dengan unsur magis, mitos, legenda dan falsafah, perwatakan diperkait dengan latar dan sejarah, banyak deskripsi fikiran daripada fizikal, latar sosial mempengaruhi perkembangan jalur cerita/pemikiran dan sering terjadi pertentangan. Realisme magis 
digunakan pengarang untuk menutup pemikiran politik kerana persoalan politik terselindung dalam situasi unreal supaya protesnya tidak ketara.

Sehubungan itu, ciri-ciri inilah yang menonjol dan mewarnai novel EMTSA sebagai sebuah karya yang beraliran realisme magis. Pengarang mengemukakan peristiwa pada masa ini, iaitu selepas merdeka bertindih dengan masa silam, iaitu sekitar tahun 1800-an atau sebelum merdeka iaitu pada zaman penjajahan James Brooke iaitu sekitar tahun 1841. Peristiwa cicit Mem Rosalinda, iaitu Edward Blair Jr yang berada di tengah laut iaitu di Selat Melaka pada masa ini atau selepas merdeka untuk mencari khazanah bangsanya dibaur dan diselangselikan dengan kisah zaman silam iaitu kisah Mem yang memulakan kehidupan di gereja St Anthony, Brooklyn melalui imbas kembali cicitnya. Kemudian, peristiwa masa ini tentang Edward Blair Jr dibaurkan dengan imbas kembali Mem tentang zaman silam iaitu kisah Mem dan Rentap. Peristiwa zaman ini berselang seli dengan peristiwa zaman silam yang diimbas kembali oleh Mem dan cicitnya Edward Blair Jr membauri novel ini dari awal sehingga ke akhir cerita. Peristiwa ini dapat diperkait dengan latar masa yang sengaja dibentuk pengarang. Pertindihan peristiwa masa kini, silam dan lampau (melalui imbas kembali) merupakan ciri karya yang beraliran realisme magis.

Teknik penceritaan dan peristiwanya berkeadaan begitu kerana plot yang tidak kronologis atau pun lebih tepatnya bersifat jungkir balik. Cerita yang dipaparkan tiada urutan masa dan latar tempatnya juga tidak tetap kerana penceritaan sudah tidak mementingkan plot tetapi peristiwa dan pemikiran. Zaman ini berlatarkan dunia Barat dan Kepulauan Borneo yang sudah mengecapi kemajuan dan kecanggihan selepas merdeka. Zaman silam pula berlatarkan gereja St Anthony di Brooklyn, kadangkadang di Kepulauan Borneo khususnya di Rumah Panjang Kerangan Panggil dan ada kalanya di dunia sebayan iaitu dunia selepas mati bagi masyarakat Iban melalui mimpi dan halusinasi Mem. Zaman lampau melalui imbas kembali Mem kebanyakannya berlatarkan dunia fantasi seperti dunia dewa-dewi, dunia mimpi dan dunia realiti di Rumah Panjang Kerangan Panggil dan Kepulauan Borneo. Dunia dewi dewi misalnya, menceritakan keluarbiasaan kelahiran Rentap yang merupakan anak dewa dari Panggau Libau yang penuh dengan unsur fantasi dan mitos. Pengarang memanfaatkan teknik imbas kembali dengan semaksimumnya dalam novel ini agar penceritaan menjadi lebih berkesan dan memberikan kesan kepada plot sehingga mencabar minda khalayak untuk berfikir.

Plot novel bertindih dan berselang seli dan kadang-kadang mengelirukan pembaca. Latar dan peristiwa yang bertindih dalam novel ini amat menuntut pembacaan yang teliti. Pemaparan novel ini adalah dalam bentuk akrostik (puzzle) bergambar yang disengajakan untuk mencabar diri beliau dan secara tidak langsung mencabar pemikiran pengkritik. Beliau menulis novel ini tanpa bab-bab, berselang seli dengan penampilan plot/subplot yang mengelirukan pembacaan. Pengarang memperlihatkan teknik keterpecahan seperti dislocation kerana latarnya tidak tetap. Pengarang menyentuh dunia fantasi tatkala mengisahkan kebesaran dan keajaiban dewa-dewi yang diagungkan kaum Iban sehingga dapat menyediakan mimpi kepada mereka untuk ke Panggau Libau. Panggau Libau ialah tempat di antara langit dan bumi yang menjadi tempat kediaman dewa-dewi dalam masyarakat Iban (Jimmy Donald, 1998). Kadang-kadang dunia realiti zaman silam dibaur dan dikaburkan dengan dunia halusinasi Mem iaitu Mem ke dunia sebayan, dunia selepas mati ketika duduk di kerusi goyang. Sesungguhnya, novel ini lebih sarat dengan deskripsi fikiran atau minda melalui unsur mimpi dan penceritaan tentang dunia kayangan dewa-dewi dan Rentap dibandingkan dengan aspek fizikal. Mem berhalusinasi antara mimpi dan realiti ke dunia sebayan dan berjumpa Rentap kekasihnya. Rentap ditemuinya di rumah panjang di Kerangan Panggil dan sedang menunggu kedatangan Mem. Rentap bertanya Mem tentang khazanah bangsa mereka yang amat berharga dan bimbang khazanah itu jatuh ke tangan manusia Barat yang pasti memanipulasikan khazanah itu untuk kepentingan mereka. Mimpi Mem sebenarnya menjadi petanda yang Mem juga akan dijemput ke dunia sebayan seperti mereka yang telah menghuninya kerana tidak lama selepas Mem Rosalinda atau Rita bermimpi, dia telah dijemput ke dunia sebayan dalam perjalanan pulang ke Kepulauan Borneo (Jong Chian Lai, 2009). Kisah ini disampaikan pengarang menerusi deskripsi fikiran Mem Rosalinda dengan menggunakan teknik monolog dalaman. Penggunaan teknik ini amat dominan sehingga memberikan kesan jiwa terhadap peristiwa dan penceritaan.

Unsur-unsur magis dan mitos dibaurkan pengarang dalam novel ini untuk menonjolkan legasi kepahlawanan dan keperwiraan Rentap dalam menghadapi penjajah Barat yang bermotif untuk keuntungan dan penindasan. Kisah Dewa Keling memperkasakan Rentap juga sarat dengan mitos yang bergumal di dalamnya keajaiban dan penerokaan dalam dunia fantasi dewa-dewa. Pemerkasaan Rentap 
dilakukan oleh Dewa Keling, Nenek Andan dan Gelayan yang merupakan watak bukan manusia dalam masa tujuh hari setelah kelahiran Rentap. Dalam kisah ini Puteri Pelanduk muncul dan menyusukan Rentap yang kelaparan. Nenek Andan dapat menurunkan hujan setelah membaca mantera Sebungkok dan mereka bertiga bersama-sama Rentap yang masih bayi dapat berjalan di atas belakang buaya yang hidup dalam tasik yang dikeringkan petara. Mereka turut terperangkap dalam ancaman binatang buas yang menyerupai manusia ketika hendak mencari batu emplias dan terjatuh di atas paku pakis gergasi lalu bertembung dengan gergasi Buga Setua Tui. Bayi, iaitu Rentap diberi makan muntah gergasi kerana di dalam muntah ada batu emplias. Batu ratai pula akan dimuntah ular di rumah panjang (Jong Chian Lai, 2000). Penggunaan unsur mitos dan fantasi ini mengukuhkan teks ini beraliran realisme magis hasil penyelidikan dan pembacaan yang meluas dan mendalam oleh pengarang.

Kuasa magis yang dimiliki Rentap menggerunkan orang Barat, apatah lagi disaratkan dengan mitos sehingga Rentap menjadi lagenda dalam masyarakat Iban dan disanjung tinggi. Mitos mewarnai Rentap apabila Rentap bertukar menjadi gergasi dan dapat mengangkat ular besi dan meletakkannya di landasan keretapi. Kepala Rentap juga tidak lut apabila Garan membelah kepalanya dengan ilang, sebaliknya Garan yang mati. Rentap turun ke sungai dan muncul bersama-sama buaya dan membesar menjadi gergasi. Kebanyakan yang hadir ketakutan termasuk Tuan sehingga terkencing apabila Rentap menyentuh kepalanya. Unsur mitos mengangkat Rentap sebagai pahlawan yang digeruni penjajah walaupun sukar untuk mereka mengakuinya. Penggunaan unsur mitos menggambarkan kebijaksanaan pengarang dalam menerokai unsur tradisi sesuatu bangsa yang bukan sekadar diwarisi tetapi harus difahami dengan mendalam. Pengarang memperlihatkan kesedaran dan kekuatan menguasai mitosmitos bangsa Iban hasil ketekunan dan penelitian jitu beliau membuat pembacaan terhadap buku-buku hikayat masyarakat Iban. Pengarang berbuat demikian adalah untuk mengangkat maruah dan memberi pemikiran yang tinggi kepada bangsa yang selalu menjadi fokus penciptaan beliau khasnya golongan terpinggir. Novel yang beraliran realisme magis juga memaparkan watak yang berkaitan dengan latar dan sejarah seperti watak Rentap dan Tuan yang memang wujud dalam sejarah dan latar zaman silam di Kepulauan Borneo. Di samping sarat dengan elemen mitos dan unsur magis novel yang beraliran ini juga ada falsafah. EMTSA mengutarakan falsafah tentang bangsa yang berjiwa besar dan berani adalah bangsa yang tahu menghargai budaya dan tradisinya sendiri.

Secara rangkumannya, berdasarkan peristiwa yang bertindih antara zaman silam dan kini, elemen-elemen magis, mitos, legenda dan falsafah, perwatakan yang berkait dengan latar dan sejarah, adanya pertentangan dan deskripsi fikiran lebih banyak daripada fizikal, maka EMTSA adalah sebuah karya yang beraliran realisme magis. Unsur magis, mitos, dunia mimpi yang berbaur dalam novel ini merupakan metode pengarang untuk menggema dan menggembar-gemburkan kelebihan, keistimewaan dan ketinggian kuasa minda manusia Timur yang sukar diyakini manusia Barat di samping menggambarkan yang tamadun Timur lebih tinggi kuasa mindanya daripada Barat. Mitos dewa dewi yang dilipurkan dalam novel ini menggambarkan kekayaan folklor bangsa yang penuh dengan unsur supernatural. Unsur-unsur kesaktian dan magisme yang sukar diterima akal dan rasional dieksploitasi pengarang bagi memperlihatkan kekayaan magis dan kehalusan peradaban manusia Timur. Unsur magis yang dilimpahkan pada Rentap mungkin juga satu perutusan politik antipenjajah pengarang melalui novel ini. Tambahan pula pengarang mahu bangsa ini memikirkan secara serius tentang politik, ekonomi dan sosial demi masa depan bangsa. Pemimpin pula harus ada sifat kebijaksanaan dan kekuasaan daya pemikiran serta sanggup berkorban demi bangsanya seperti pengorbanan Rentap untuk mengejar kemajuan dan pembangunan minda dan fizikal bagi bangsanya. Semua elemen dan unsur ini digembleng dan dipadukan oleh pengarang berdasarkan sumber idea daripada penyelidikan, pembacaan dan rujukan yang dilakukan oleh beliau dengan mendalam. Kesepaduan teks ini menggambarkan tindakan seorang pengarang yang bersungguh-sungguh dalam membuat penyempurnaan dalam menghadirkan sumber idea bagi mencapai visi dan misinya sebagai penulis. EMTSA merupakan suara hati penulis yang mahu menyemai kesedaran kepada sesuatu bangsa itu agar memajukan minda sekali gus tidak ketinggalan dalam arus pembangunan. Novel ini juga menggambarkan usaha pengarang untuk mengangkat maruah bangsa Timur agar tidak dipandang rendah oleh manusia Barat. 


\section{KESIMPULAN}

Prinsip Kehadiran dalam teori Teksdealisme menuntut pengarang untuk menghadirkan pelbagai pengalaman dengan membuat penyaringan, pemilihan dan penyatupaduan bagi menghasilkan jalinan peristiwa yang kemas mantap dan menarik. Aspek-aspek yang membina teks dijalin, dibaur dan disebatikan sehingga wujud kesepaduan dalam teks tersebut. Teksdealisme turut menekankan bahawa teks yang unggul dapat dilahirkan oleh pengarang yang kaya dengan pengalaman, bijak, berani meneroka, bersifat inovatif tidak hanya berada di takuk lama dengan menghasilkan karya yang konvensi sifatnya. Teksdealisme menuntut pengkarya agar menghasilkan karya yang bersifat avant garde agar karya yang terhasil setanding dengan karya-karya bermutu oleh penulis-penulis dunia terkenal. Teksteks yang unggul juga memerlukan pengarang membuat pengukuhan dari teks ke sebuah teks yang lain. Pengarang yang berhasrat untuk menjadi unggul akan berusaha memastikan teks-teks yang dihasilkan lebih bermutu daripada sebelumnya dengan membuat pemantapan dan penyempurnaan dari pelbagai sudut. Jong Chian Lai telah membuat pemantapan dan penyempurnaan dari segi menghadirkan sumber idea yang menunjukkan pembaharuan dan variasi dari segi subjek-subjek, watak, latar yang lebih luas dan holistik sifatnya, teknik penceritaan dan aliran penciptaan.

Berdasarkan analisis, didapati Jong Chian Lai telah membuat pemberontakan dan pembaharuan sebagaimana yang dituntut Teksdealisme dalam novel Pemberontakan dan EMTSA setelah penghasilan GLHNT. Beliau tidak lagi terpenjara dan dikongkong oleh penciptaan teks menerusi sumber idea berdasarkan pengalaman peribadi sebagaimana dalam GLHNT. Beliau mengorak langkah dengan menghadirkan sumber idea yang lebih segar, baharu dan lebih holistik terutama dalam Pemberontakan dan EMTSA. Beliau tidak mengekalkan sumber idea dari pengalaman peribadi kerana tidak mahu berada ditakuk lama sebaliknya mematuhi gagasan Teksdealisme. Pemberontakan dan EMTSA merupakan teks yang terhasil daripada sumber idea menerusi penyelidikan yang mendalam dan meluas menerusi pembacaan dan penelitian yang menyeluruh sepanjang berkarya. Hal ini bermakna Jong sentiasa bekerja keras dan bertindak dengan berani, inovatif dan bijaksana dalam meningkatkan mutu karya yang dicipta. Walaupun Jong membuat pengekalan dari segi kehadiran sumber idea dalam kedua-dua novel ini menerusi penyelidikan namun fokus dan aspek penyelidikannya berbeza. Pemberontakan memperlihatkan Jong kembali menyingkap sejarah silam tetapi EMTSA pula menuntut Jong untuk membongkar, menggali, meneroka dan menjungkir balik sejarah silam untuk mengangkat maruah bangsa Timur agar tidak dipandang rendah oleh dunia Barat. Perubahan yang dilakukan oleh Jong menunjukkan beliau seorang pengkarya yang sangat berani dan bijaksana dalam menukangi teks ciptaannya agar memperlihatkan pembaharuan dan idea yang mantap.

Aspek struktur pula memperlihatkan kehadiran pelbagai subjek, watak dan latar yang memperlihatkan kelainan dan perluasan. GLHNT yang dihasilkan pada tahun 1983, menghadirkan kepekaan diri pengarang terhadap nasib golongan etnik yang terpinggir khususnya masyarakat Iban daripada arus pembangunan. Oleh itu, subjek-subjek yang dihadirkan dalam novel ini adalah seperti kecintaan terhadap hutan, pembalakan haram, penindasan, penipuan, kepincangan masyarakat, kemunduran ekonomi, kemiskinan dan persahabatan. Subjek-subjek ini masih berlegar pada permasalahan semasa masyarakat di sesuatu tempat dan masih berada dalam kepompong Ibanisme. Sementara dalam Pemberontakan, pengarang menghadirkan subjek seperti penentangan, penindasan, kepincangan masyarakat, ekonomi, politik, pembelotan, perpaduan dan penjajahan. Subjek-subjek ini ternyata lebih meluas dan holistik dibandingkan dengan GLHNT kerana mencakupi penjajahan oleh kuasa Barat di Kepulauan Borneo. Perjuangan dalam Pemberontakan berbeza dengan perjuangan dalam GLHNT. Perjuangan dalam GLHNT hanya perjuangan kerdil watak Jabau menentang pembalakan haram tetapi dalam Pemberontakan, perjuangan lebih holistik kerana melibatkan tiga kaum di Kepulauan Borneo menentang penjajah. Dalam EMTSA pula pengarang menghadirkan subjek-subjek yang lebih holistik, komprehensif dan mencakupi pelbagai bidang seperti politik, feminisme, pengorbanan, penentangan, penindasan, ekonomi, perlanggaran adat, penjajahan baharu, budaya, politik, kebijaksanaan, kuasa magis, mitos dan marin arkeologis yang melibatkan hubungan dan konflik Timur-Barat. Subjek-subjek dalam EMTSA bukan sahaja holistik dan meluas skopnya tetapi komprehensif sifatnya. Ringkasnya, subjek-subjek yang dihadirkan dalam ketiga-tiga novel memperlihatkan pembaharuan, perubahan dan kelainan. Aspek latar dan watak dalam ketiga-tiga novel juga memperlihatkan berlakunya perubahan dan pembaharuan. Watak dalam GLHNT masih berada 
dalam kepompong Ibanisme kerana memberikan fokus terhadap masyarakat Iban di Nanga Tiga. Sementara dalam Pemberontakan, watak-wataknya merangkumi tiga kaum besar di kepulauan Borneo iaitu kaum Iban, Melayu dan pekerja lombong yang berhijrah dari China. EMTSA pula lebih holistik dan komprehensif kerana mencakupi watak manusia Timur, Barat dan watak bukan manusia biasa seperti dewa-dewi, gergasi dan haiwan ganas. Latar juga lebih luas dan pelbagai merangkumi dunia Barat secara langsung seperti Gereja St Anthony, Brooklyn dan dunia sebayan dalam EMTSA dibandingkan dengan Pemberontakan dan GLHNT.

Pengarang juga membuat pembaharuan dan pengukuhan terhadap aliran dalam ketiga-tiga novel. EMTSA telah meninggalkan aliran realisme dalam GLHNT dan Pemberontakan. Pengukuhan aliran khusunya aliran realisme berlaku dalam dua buah teks, iaitu GLHNT dan Pemberontakan. Seterusnya, beliau membuat pembaharuan dalam EMTSA. Aliran realisme magis yang pekat dalam EMTSA mendalilkan keberhasilan pengarang memanfaatkan penggunaan pelbagai teknik seperti teknik imbas kembali, monolog, monolog dalaman dan deskripsi fikiran sebagai medium penyampaian idea. Penggunaan teknik-teknik ini mengukuhkan ciri-ciri aliran realisme magis sehingga dapat menyampaikan ideologi, pemikiran dan falsafah secara tersirat sekali gus memperlihatkan pengaplikasian naratif penceritaan yang baharu. Pengukuhan aliran ini menempatkan novel ini sebagai karya yang bersifat internasional dan memberi sumbangan terhadap karya sastera pascamoden. Novel yang beraliran realisme magis ini bukan sahaja menyumbang terhadap kelahiran teks yang bermutu malah turut menyumbang terhadap kelahiran teks-teks pascamoden dan avant-garde yang sarat dengan ciri-ciri pembaharuan yang tinggi mutunya.

Jong Chian Lai juga memperlihatkan sifat jati diri dan wawasannya dalam berkarya. Sumbersumber idea yang dihadirkan dalam ketiga-tiga novel mengarah kepada agenda nasional, iaitu perpaduan. Beliau mahu masyarakat sedar bahawa semangat patriotisme wajar dipraktis dan dibudayakan dalam kehidupan demi keamanan. Wawasan perpaduan amat menyerlah dalam ketiga-tiga novel kerana aspirasinya mahu masyarakat bangkit dan bersatu demi maruah bangsa.

Tuntasnya, kejayaan pengarang membuat pemantapan dan penyempurnaan menerusi pembaharuan, perubahan dan pengekalan dalam menghasilkan teks menunjukkan pengarang berusaha untuk menuju tangga keunggulan. Pembaharuan dan pemberontakan yang dilakukan untuk mengejap dan meningkatkan mutu karya menunjukkan keberanian, kepekaan dan kebijaksanaan seseorang pengarang dalam berkarya sehingga menempatkan dirinya berada pada tahap keunggulan. Berdasarkan analisis, Jong Chian Lai telah menepati prinsip kehadiran dalam ketiga-tiga novel berkenaan dari segi menghadirkan sumber idea berdasarkan pengalaman peribadi dan penyelidikan dalam berkarya.

\section{RUJUKAN}

Ariff Mohamad. (2015). Pengungkapan Keperibadian Secara Simbolik dalam Dua Novel Melayu. Jurnal Pendeta, (6), 230-243.

Augustine Anggat Ganjing. (1991). Asas ukiran Iban: satu pengenalan. Kuala Lumpur: Dewan Bahasa dan Pustaka.

A. Samad Said. (1987). Dari Salina ke Langit Petang. Kuala Lumpur: Dewan Bahasa dan Pustaka.

Buyong Adil. (1981). Sejarah Sarawak. Kuala Lumpur: Dewan Bahasa dan Pustaka \& Kementerian Pelajaran Malaysia.Frank, H. \& Robert, F.H. (1990). Arkeologi prasejarah satu pengenalan ringkas. Terj. Shakila Yaacob. Kuala Lumpur: Dewan Bahasa dan Pustaka.

Hazami Jahari. (2007, Februari). Dari Pindah ke Pemberontakan: Tingkat kematangan kepengarangan Jong Chian Lai. Kertas kerja pembentangan Wacana Pemikiran Jong Chian Lai. Balai Budaya Dewan Bahasa dan Pustaka Cawangan Sarawak, Kuching Sarawak.

Jais Sahok. (2000, April). Novel penulis pelbagai kaum. Dewan Sastera, hlm. 10-12.

Jeniri Amir. (2007, Februari). Dari Pindah ke Meredah Ombak Keributan: Dunia dalam kata, dunia beraneka gaya. Kertas kerja pembentangan Wacana Pemikiran Jong Chian Lai. Balai Budaya Dewan Bahasa dan Pustaka Cawangan Sarawak, Kuching Sarawak.

Jimmy, Donald. (1998). Hikayat Keling Gerasi Nading. Kuala Lumpur: Dewan Bahasa dan Pustaka.

Jong Chian Lai. (1986) Gugurnya Langit Hijau Nanga Tiga. Kuala Lumpur: Dewan Bahasa dan Pustaka \& Kementerian Pendidikan Malaysia.

Jong Chian Lai. (1994). Pemberontakan. Kuala Lumpur: Dewan Bahasa dan Pustaka \& Kementerian Pendidikan Malaysia. 
Jong Chian Lai. (2000, Januari). Mengepung kesabaran dalam dunia sastera. Dewan Sastera, hlm. 17-19.

Jong Chian Lai. (2006). Ucapan penerimaan S.E.A Write Award 2006. Dalam Zaiton Ajmain \& Khatijah Ismail (pnyt.). Malaysian Writer: Awardee of The S.E.A Write Awards 2006. (hlm. 5-10). Kuala Lumpur: Dewan Bahasa dan Pustaka.

Jong, Chian Lai. (2007, April). Pengalaman dalam bidang menulis novel. Dewan Sastera, hlm. 93-98.

Jong, Chian Lai. (2009). Ensera Marga Timur dari St. Anthony. Kuala Lumpur: Dewan Bahasa dan Pustaka.

Mana Sikana. (1996). Teori sastera teksdealisme. Bangi: Universiti Kebangsaan Malaysia.

Mana Sikana. (2006). Teori Sastera Teksdealisme. Singapura: Pustaka Karya.

Mana Sikana. (2007). Tokoh-tokoh unggul dalam sastera Melayu. Singapura: Pustaka Karya.

Rosnani Md Zain \& Nik Rafidah Nik Muhamad Affendi. (2017). Fenomena Sosial dalam Novel Nenek Karya Razali Endun. Jurnal Pendeta, (8), 82-95.

Safian Hussain, Mohd Thani Ahmad, Zakaria Ariffin, Ahmad Kamal Abdullah \& Suhaimi Muhamad (pngr.). (1988). Glosari istilah kesusasteraan. Kuala Lumpur: Dewan Bahasa dan Pustaka.

Shahnon Ahmad. (1979). Gubahan novel. Kuala Lumpur: Dewan Bahasa dan Pustaka.

Shahnon Ahmad. (1994). Pengalaman ilmu imaginasi dan kitarannya. Kuala Lumpur: Dewan Bahasa dan Pustaka.

Sohaimi Abdul Aziz. (1992). Mobiliti sosial perspektif Barat dan Islam dalam novel terpilih Shahnon Ahmad. Kuala Lumpur: Dewan Bahasa dan Pustaka.

Shahnon Ahmad. (2002). Unsur realisme magis melalui konsep pencerobohan dalam karya-karya awal Gabriel Garcia Marquez. Dalam Lalita Sinha (pytg.). Tradisi dan modeniti: Kesusasteraan melintasi zaman dan wilayah. (hlm. 129-138). Pulau Pinang: Penerbit Universiti Sains Malaysia.

Siti Khariah Mohd Zubir \& Nur Aisyah Abdullah, (2015) Pemikiran Khadijah Hashim dalam novel Badai Semalam dan Laila Azwa Gadisku untuk membangunkan sahsiah belia. Jurnal Pendeta, (5), 145-173.

Sohaimi Abdul Aziz. (2002). Unsur sejarah dalam metafiksyen historiografik: Satu pemikiran pascamoden. Dalam. Lalita Sinha (pytg.). Tradisi dan modeniti: Kesusasteraan melintasi zaman dan wilayah. (hlm. 139-157). Pulau Pinang: Penerbit Universiti Sains Malaysia.

Tengku Intan Marlina Tengku Mohd. Ali, Madiawati Mamat@Mustaffa \& Fauzi Hasan. (2017). Novel-novel Faisal Tehrani dari Perspektif Teksdealisme. Jurnal Pengajian Melayu, (28), 262-287.

Ungku Maimunah Mohd. Tahir. (1996, Januari). Elemen realisme magis dalam Hujan Pagi: Satu kajian berdasarkan novel One Hundreds Years of Solitude karya Gabriel Garcia Marquez. Dewan Sastera, hlm. 20-27.

Zuriyah Jemy. (2003). Isu pembangunan menerusi novel-novel Jong Chian Lai. Tesis sarjana yang tidak diterbitkan. Jabatan Persuratan Melayu. Bangi: Universiti Kebangsaan Malaysia. 